SCHOOL OF PUBLIC HEALTH

COLLEGE OF MEDICINE AND HEALTH SCIENCES

UNIVERSITY OF GONDAR

ASSESSMENT OF HOUSEHOLD FOOD INSECURITY AND ASSOCIATED FACTORS IN RURAL COMMUNITIES OF GONDAR CITY ADMINISTRATION

By: $\quad$ Yirdaw Melese

ADVISORS: -Mengesha Admassu (Professor)

-Mesafint Molla (RS, BSc, MPH)

A THESIS SUBMITTED TO THE SCHOOL OF PUBLIC HEALTH, COLLEGE OF MEDICINE AND HEALTH SCIENCES, UNIVERSITY OF GONDAR IN PARTIAL FULFILLMENT OF THE REQUIREMENTS FOR THE DEGREE OF MASTER OF PUBLIC HEALTH

JULY 2011

GONDAR, ETHIOPIA

ABC Research Alert, Vol 2, No 2 (2014) 


\author{
UNIVERSITY OF GONDAR \\ COLLEGE OF MEDICINE AND HEALTH SCIENCES \\ SCHOOL OF PUBLIC HEALTH
}

\title{
ASSESSMENT OF HOUSEHOLD FOOD INSECURITY AND ASSOCIATED FACTORS IN RURAL COMMUNITIES OF GONDAR CITY ADMINISTRATION
}

\author{
By: $\quad$ Yirdaw Melese \\ Telephone: $\quad+251-918-78-99-22$ \\ E-mail Address: yirdawy@gmail.com
}

Approved by the Examining Board

Head, School of public Health

Signature

\section{Advisors}

1.

2. 


\section{Acknowledgement}

I would like to thank my advisors Prof. Mengesha Admassu and Mr. Mesafint Molla for their valuable advice, critical comments and suggestions throughout the thesis development. My deep gratitude goes to Mr. Tesfahun Melese whose continuous guidance and financial support and unreserved advice made this paper to happen. I am also indebted to Mr. Yifokir Tefera and all Environmental and Occupational Health staff members who have supported me a lot throughout the course of this paper. I am also grateful for all academic staff of School of Public Health, College of Medicine and Health Sciences, University of Gondar for their support in one or another way in preparing this thesis. I would like to extend my appreciation to my colleagues, especially, Asresu Tariku for their support during the course of the paper. I want to extend also my thanks to members of Gondar City Administration Health and Trade and Industry Offices for providing me all the necessary information. Finally, my sincere thank goes to the study team (supervisors and data collectors) and study participants for their willingness to participate in the study. 


\section{Acronyms}

$\begin{array}{ll}\text { AIDS } & \text { Acquired Immune Deficiency Syndrome } \\ \text { AOR } & \text { Adjusted Odds Ratio } \\ \text { CI } & \text { Confidence Interval } \\ \text { COR } & \text { Crude Odds Ratio } \\ \text { CARD } & \text { Council for Agricultural and Rural Development } \\ \text { FANTA } & \text { Food and Nutrition Technical Assistance } \\ \text { FAO } & \text { Food and Agricultural Organization } \\ \text { FFP } & \text { Food For Peace } \\ \text { ha } & \text { Hectare } \\ \text { HFIAP } & \text { Household Food Insecurity Access Prevalence } \\ \text { HFIAS } & \text { Household Food Insecurity Access Scale } \\ \text { HH } & \text { Household } \\ \text { HIV } & \text { Human Immune Deficiency Virus } \\ \text { MDGs } & \text { Millennium Development Goals } \\ \text { PSNP } & \text { Productive Safety Net Program } \\ \text { OR } & \text { Odds Ratio } \\ \text { Q } & \text { Question } \\ \text { SE } & \text { Standard Error } \\ \text { SNNP } & \text { Southern Nation Nationalities and People } \\ \text { SPSS } & \text { Statistical Package for Social Science } \\ \text { SRS } & \text { Simple Random Sampling } \\ \text { TWG-FSN } & \text { Technical Working Group for Food Security and Nutrition } \\ \text { UNDP } & \text { United Nations Development Program } \\ \text { USAID } & \text { United States Agency for International Development } \\ \text { USDA } & \text { United States Department of Agriculture } \\ \text { WFP } & \text { World Food Program } \\ & \end{array}$




\section{Table of Contents}

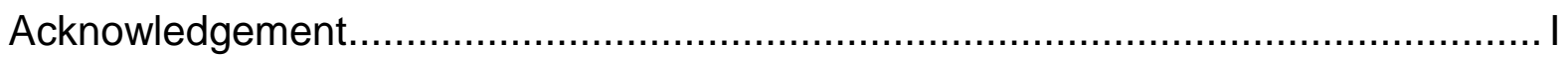

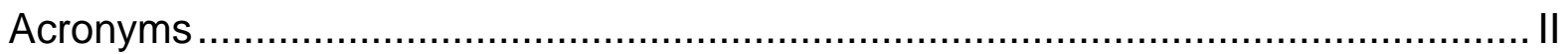

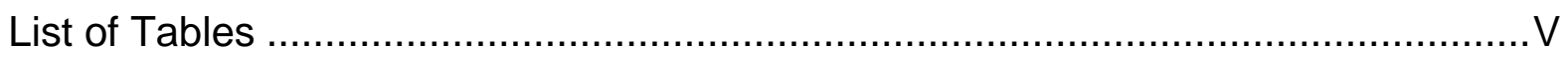

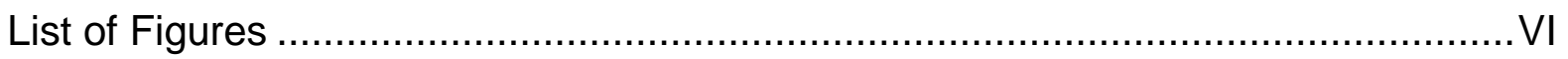

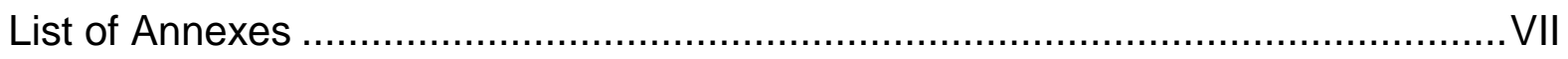

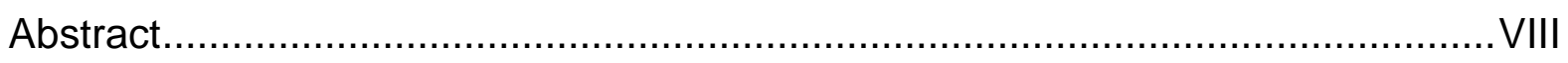

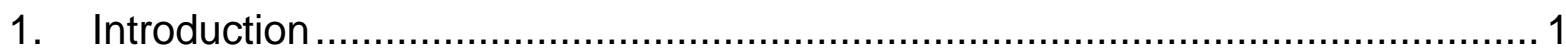

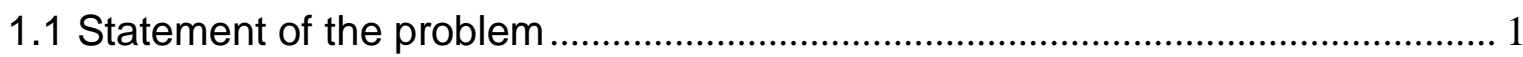

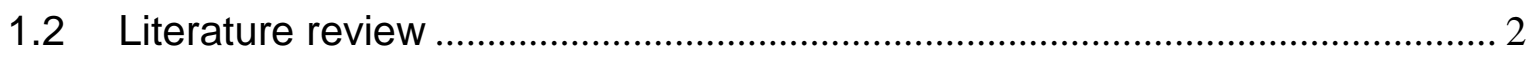

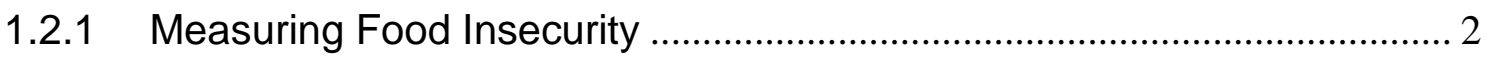

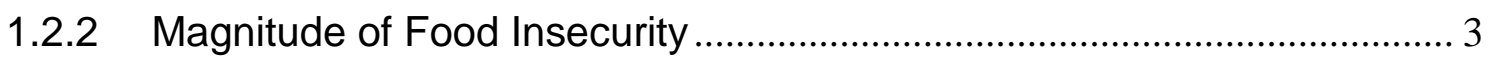

1.2.3 causes of Food Insecurity and consequences ......................................... 4

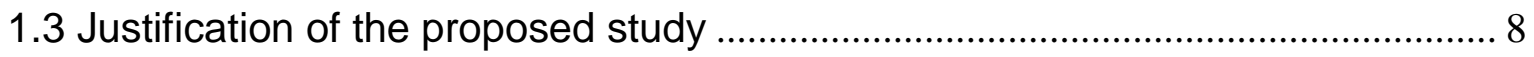

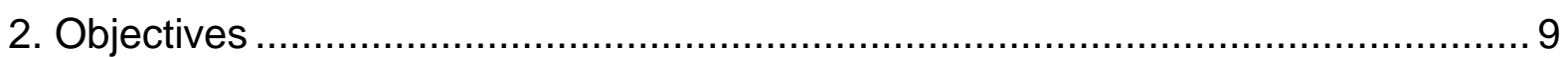

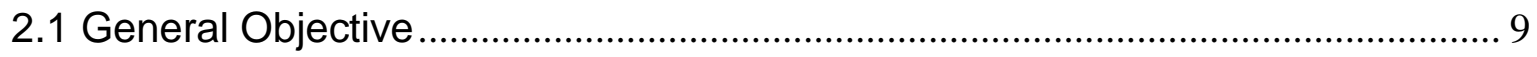

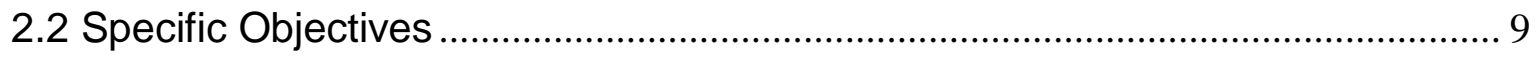

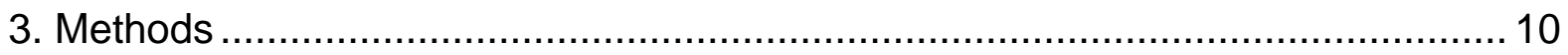

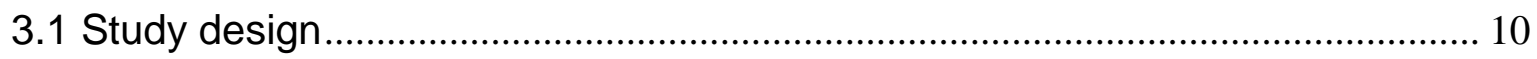

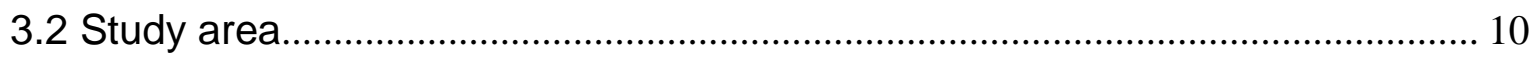

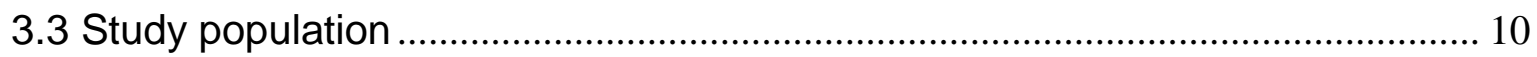

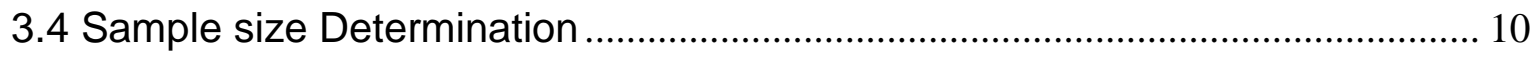

3.5 Sampling procedures ..................................................................................... 11

3.6 Data collection procedure ………………….................................................. 12

3.7 Variables of the study .................................................................................. 13

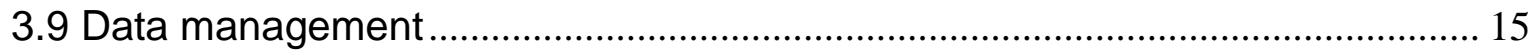

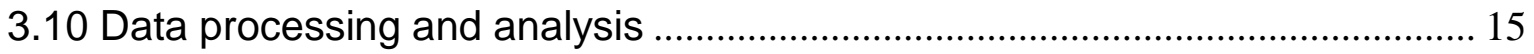

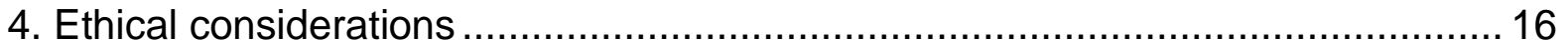

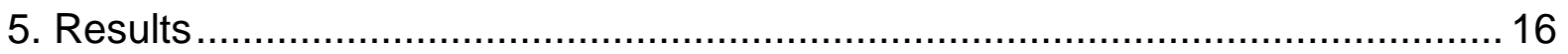

5.1 Socio-demographic characteristics of household heads .................................... 17

5.2 Household food insecurity level of the study area.............................................. 23

5.3 Factors associated with household food insecurity status................................. 25 


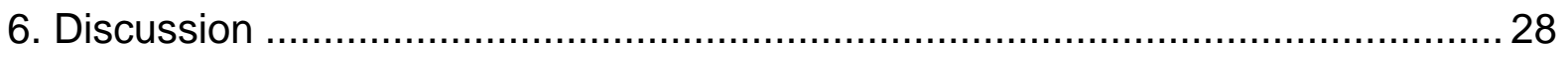

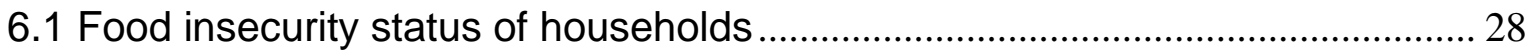

6.2 Factors associated with household food insecurity............................................ 29

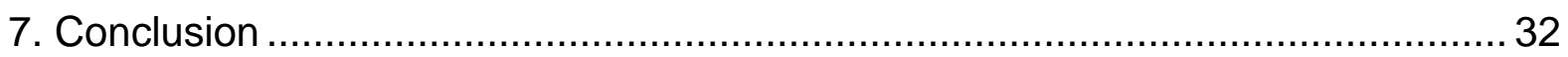

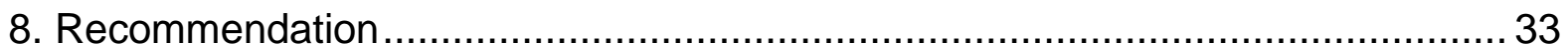

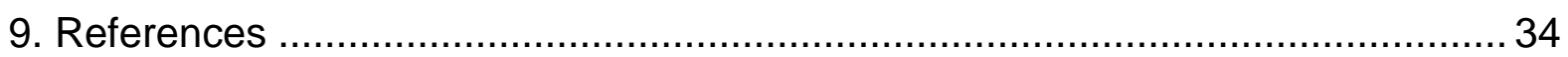

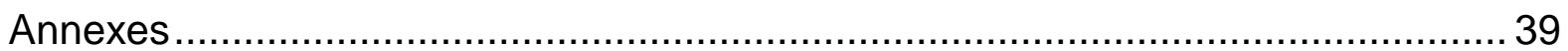

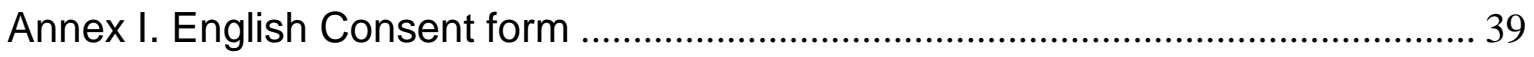

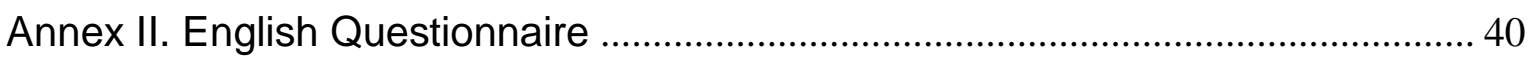

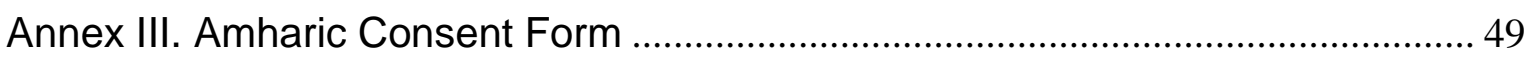

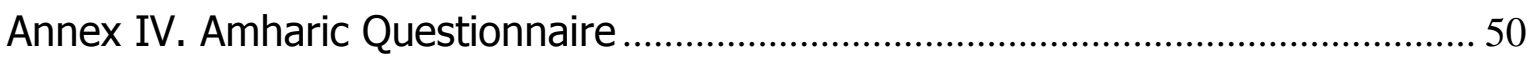

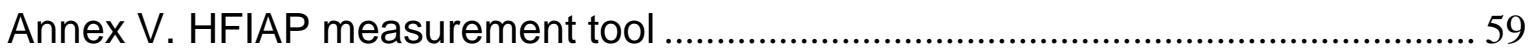

Annex VI. Food insecurity status by some socio-economic characteristics in rural

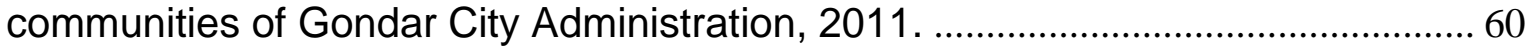

Annex VII. Operational Manual for Data Collectors(English) .................................... 64

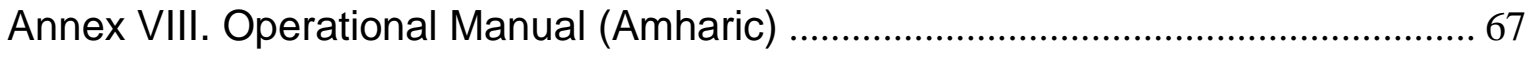

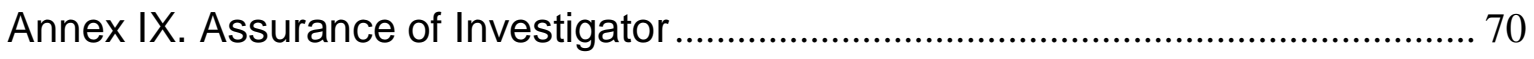

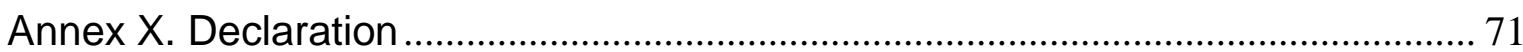




\section{List of Tables}

Table 1 Socio-demographic characteristics of household head in rural community of Gondar City Administration, 2011.

Table 2 Housing conditions and household assets in rural communities of Gondar City Administration, 2011.

Table 3 Farm related characteristics of households in rural communities of Gondar City Administration, 2011.

Table 4 Water and sanitary conditions of households in rural communities of Gondar City Administration, 2011.

Table 5 Food insecurity condition of households in rural communities of Gondar City Administration, 2011.

Table 6 Results of logistic regression for selected variables on household food insecurity in rural communities of Gondar City Administration, 2011. 


\section{List of Figures}

Fig.1 Conceptual framework for household food insecurity

Fig.2 Schematic representation of sampling procedure

Fig.3 Food insecurity status in rural communities of Gondar City Administration, 2011. 


\title{
List of Annexes
}

\author{
Annex I Consent form (English) \\ Annex II English questionnaire \\ Annex III Consent form (Amharic) \\ Annex IV Amharic questionnaire \\ Annex $\mathrm{V} \quad \mathrm{HFIAP}$ measurement tool \\ Annex VI Food insecurity status by socio-economic characteristics in \\ rural communities of Gondar City Administration, 2011. \\ Annex VII Operational manual for data collectors (English) \\ Annex VIII Operational manual for data collectors (Amharic) \\ Annex IX Assurance of investigator \\ Annex $X \quad$ Declaration
}




\begin{abstract}
Background:-Ethiopia is currently ranked 169 out of 177 countries on the 20072008 Human Development Index and is chronically suffers from food insecurity. Food shortages in Ethiopia aggravate the already poor health of children and adults. Millions of households in rural areas of Ethiopia suffer from chronic food insecurity and receive food aid on an annual basis.

Objective:-This study was conducted to determine prevalence of household food insecurity and its associated factors in rural communities of Gondar City Administration, North West Ethiopia.

Methods:-Community based cross-sectional study design was employed. Data were collected through house to house interview using household food insecurity access scale (HFIAS) which is structured and universally applicable household food insecurity 9 item measurement tools. Descriptive statistics and logistic regressions were used to determine prevalence of household food insecurity and its associated factors.

Result: $-60.8 \%$ of the rural households were found to be food insecure in the study area. Out of the total eleven variables included in the logistic regression analysis model only 6 variables namely; livestock ownership $(A O R=2.05,95 \% \mathrm{Cl}=1.039$ 4.022), use of fertilizer $(A O R=4.23,95 \% \mathrm{Cl}=1.741-10.275)$, source of potable water $(\mathrm{AOR}=4.00,95 \% \mathrm{Cl}=2.060-7.764)$, off-farm income $(\mathrm{AOR}=2.90,95 \% \mathrm{Cl}=$ 1.249-6.712), annual farm income $(\mathrm{AOR}=3.98,95 \% \mathrm{Cl}=2.514-6.303)$ and total annual income $(\mathrm{AOR}=3.93,95 \% \mathrm{Cl}=2.471-6.258)$ were found to be statistically significant.
\end{abstract}

Conclusion and recommendation: - The majority (60.8\%) of households in rural communities of Gondar City Administration is food insecure and factors like livestock ownership, use of fertilizers, source of potable water, off-farm income, farm income and total annual income are found to be significantly associated with household food insecurity in the study area. Thus, Government bodies, NGOs and the community at 
large should work cooperatively in areas that enable rural households to minimize the problem of food insecurity by overcoming factors associated with it. 


\section{Introduction}

\subsection{Statement of the problem}

Ethiopia is currently ranked 169 out of 177 countries on the 2007-2008 Human Development Index and is chronically suffers from food insecurity. Food shortages in Ethiopia aggravate the already poor health of children and adults. Millions of households in rural areas of Ethiopia suffer from chronic food insecurity and receive food aid on an annual basis. The chronic and severe food insecurities that have characterized Ethiopia over the last several decades have exacerbated the already serious obstacles facing the country's economic and social development. [1-4] Gondar City Administration is one of the 4 City Administrations in North Gondar Administrative Zone of Amhara Region. It is located at a latitude and longitude of $12^{\circ} 36^{\prime} \mathrm{N} \_37^{\circ} 28^{\prime} \mathrm{E} / 12.6^{\circ} \mathrm{N} 37.467^{\circ} \mathrm{E}$ with an elevation of 2133 meters above sea level. Economically most of the rural communities are farmers and involved production of annual crops in rain fed agriculture. While some are working as daily laborers and small scale merchants and very few work in government institutions.[5]

Food accessibility was limited due to a weak subsistence-agriculture-based economy, depletion of assets, absence of income diversity and a lack of alternative coping mechanisms. Food intake adequacy was rarely achieved due to food shortages, improper diet and poor sanitary conditions. With respect to agriculture in developing countries, the combined effect of population growth, increased per capital income and changes in dietary pattern will bring about continuous increases in demand for food and other agricultural products. [6, 7]

Even though the struggle to achieve food security at the household level in the rural areas of Ethiopia dates back a long period, it has remained as a challenging goal even today. The majority of the billion people affected by hunger live in rural areas

which includes rural poor (e.g. small farmers, landless farm laborers) are particularly vulnerable to food insecurity. [8, 9] So that, this research is designed to assess current status of the problem and associated factors and will suggest possible recommendations. 


\subsection{Literature review}

\subsubsection{Measuring food insecurity}

The discovery that people who frequently did not have enough to eat according to accepted cultural norms created a conceptual crisis. Internationally, the phrase Food Insecurity was already current. Originally, it was used to describe the instability of national or regional food supplies over time until the mid 1970s. It was then expanded to include a lack of secure provisions at the household and individual level. Food security is built on four pillars. These are food availability, food access, food use and stability of food supply over time.[9-11]

Food insecurity exists when people, at some time, do not have physical, social and economic access to sufficient, safe and nutritious food which meets their dietary needs and food preferences for an active and healthy life. Household food insecurity is defined by the United States Department of Agriculture (USDA) as difficulty of providing enough food for all household members due to lack of resources at some time during the year. [11, 12]

Four categories of household food security status scale (food secure, mildly food insecure, moderately food insecure and severely food insecure) have been defined which are often useful for policy and research purposes. Each category represents meaningful range of severity on the underlying scale, and used to discuss the percentage of the population in each of these categories.[13]

The concept of food security has been used extensively at the household level as a measure of welfare and attempts have been made to make the concept operationally useful in the design, implementation, and evaluation of programs, projects and policies. Experimental measures of food insecurity, attempt to address the issue of varying household needs and behavior. A set of questions addressed to food insecure households is used to estimate household food insecurity scores. These questions attempt to capture perceptions as well as past experience by the households. [14] 
Validation and usefullness of the Household Food Insecurity Access Scale (HFIAS) as a measure of household food insecurity (access) status, has become progressively improved through field validation studies(Cornell in Burkina Faso with Africare, Tufts in Bangladesh with World Vision, and Freedom from Hunger in Burkina Faso, Bolivia, Ghana, and the Philippines). Findings from a study conducted in Addis Ababa indicate that an adapted version of the HFIAS is a valid tool for assessing food insecurity among community health volunteers.[15,16]

\subsubsection{Magnitude of food insecurity}

One in five people today suffer from hunger and malnutrition, the effects of which on the physical and mental growth of those affected can be irreversible in some cases. Not only is hunger morally unacceptable, but it also acts as a brake on economic and human development in the poorest countries. In 2010, Food and Agricultural Organization (FAO) estimates 925 million hungry people throughout the world. Among the above figure, developing countries account for 98 percent of the world's undernourished people.[9, 17]

There is no question that lack of food security is a real and significant public health issue facing low-, medium-, and high-income countries. While it is difficult to get an accurate picture of its true extent because of variations in the methods of measurement within and among countries, high-income nations do not appear to be affected rarely. For example, reports of food insecurity in high-income countries include the following: 29\% amongst low-income households in the United Kingdom, $20 \%$ of households with children in New Zealand, in Canada is $9 \%$ and $5 \%$ in Australia. According to USDA, in 2008 the prevalence of food insecurity in the United States was $14.6 \%$ of households (17 million households) and $16.4 \%$ among individuals which was the highest recorded since 1995 when nationally representative surveys were initiated.[18-21]

In India the result of urban households' food insecurity survey in 2010 showed that prevalence of any form of food insecurity was present in three-fourths of the households $74.6 \%$.[22] In rural Tanzania $36 \%$ of households was food insecure in 2005.[23] Another study in rural Tajikistan states out of three food insecure 
households, one is severely food insecure $(12 \%, 22 \%$ and $66 \%$ of households are severely food insecure, moderately food insecure and food secure respectively). [24]

In 2005 the proportion of undernourished people in rural areas of Ethiopia was estimated to be $45 \%$ and a total of 7.5 million chronically food insecure people received Productive Safety Net Program (PSNP) assistance in 2009. Different studies in areas such as rural Amhara, rural Dire Dawa, and Southern Nation Nationalities and People (SNNP) (Bilate watershed that transects Hadiya, Kembata Tembaro, Wolaita and Sidama zones and Alaba district) showed that household food insecurity was found to be a severe problem with $45 \%, 76 \%$ and $73 \%$ respectively. [25-29]

The result of a cross sectional study conducted in selected woredas of four Regions: Amhara, Oromia, SNNP and Tigray Regions using HFIAS, showed that the food insecurity level of rural households was calculated to be $6(0.6 \%)$ food secured, $42(4.1 \%)$ mildly insecure, 404(39.9\%) moderately insecure, and 561(55.4\%) are severely insecure.[30]

\subsubsection{Causes of food Insecurity and factors associated with it}

The causes of food insecurity are both temporary and structural. Poverty, insufficient access to health and education services, as well as poor governance, are the main causes of chronic food insecurity. Environmental damage, climate change and the mismanagement of natural resources are further causes of chronic food insecurity (desertification, unstable ecosystems). Chronic undernourishment (food insecurity) in sub-Saharan Africa persists primarily due to low agricultural productivity, limited rural development, government policy disincentives, and the impact of poor health on the agricultural workforce. Additional factor, including rising global commodity prices is likely further exacerbate food insecurity in the region. $[9,31]$

A study conducted in rural households living with HIV/AIDS in Southwestern Nigeria shows that gender, education, monthly food intake (Kcal), total monthly income, drug share and food share significantly influence the food security status of the households living with HIV/AIDS. In India a study results on household food 
insecurity revealed that the presence of a significantly association with poor general health and bodily pain. While in rural Ghana the poor food insecurity status is due to a number of factors: poor biophysical conditions, skewed distribution of wealth, low social capital and few opportunities for local non-farm activities. [32- 34]

Another study in rural Nigeria showed that about one third of the rural farming households sampled was food insecure and that farm size of the households, gross farm income, total non-farm income and household size are the significant determinants of rural household food security in the study area. Traditionally, in rural Burkina Faso, livestock rearing is one of the most important strategies used by households in agro-pastoral food production systems to improve their incomes as well as their food security. Lack of livestock is one of the key markers of household vulnerability to food insecurity. Food insecurity is more concentrated among smallholder farmers and female headed households. [35, 36]

Lack of access to safe drinking water and hygienic sanitation would increase illness and infection rates and decrease health and nutritional status. People need an adequate supply of nutritious food and clean water daily to provide adequate nutrition and food security. Insufficient access to safe water sources and hygienic toilets in rural villages has strong linkages to the use of food and is a basic obstacle to improved food security and nutrition and the achievement of the Millennium Development Goals (MDGs). [37, 38]

Food intake adequacy was rarely achieved due to food shortages, improper diet and poor sanitary conditions. Studies conducted in southern Ethiopia, Eastern Oromia and Dire Dawa Regions show factors like small farmland size, low per capita aggregate production, absence of fertilizer application, large family size, low level of income, and lack of educational attainment level of household heads are identified as having a positive significant influence on food insecurity. As age of household heads' increase, they can acquire more knowledge and experience and pre - 
assume vulnerability and risk conditions of food insecurity and the chance of a household to become more food secure increases. [6, 8, 29, 39, 40]

Another studies conducted in Amhara and Southern Ethiopia regions concluded that natural factors, demographic and socio-economic factors such as large family size, high dependency ratio, low level of agriculture production, low level of livestock

wealth, low participation in off-form activities, and so on of farming are among the factors that increase the odds of food insecurity.[26, 28]

Food insecurity has been shown to be associated with poor health both in developing and developed countries and is consequently a public health issue. Food insecurity as a form of deprivation has been shown to affect many dimensions of well-being. Children from food insecure households are more likely to have poor growth attainment, recurrent infections, inadequate energy and nutrient intakes compromised learning ability and psychosocial problems.[41-44]

\subsubsection{Conceptual framework for household food insecurity}

Conceptually food insecurity is affected by socio-economic, political, institutional, cultural and natural environmental factors at national, sub-national and community, household and individual levels. These factors may determine food insecurity at different angles like food availability, accessibility, stability and/or utility. [45] The following figure shows conceptual framework of food insecurity at the household level. 


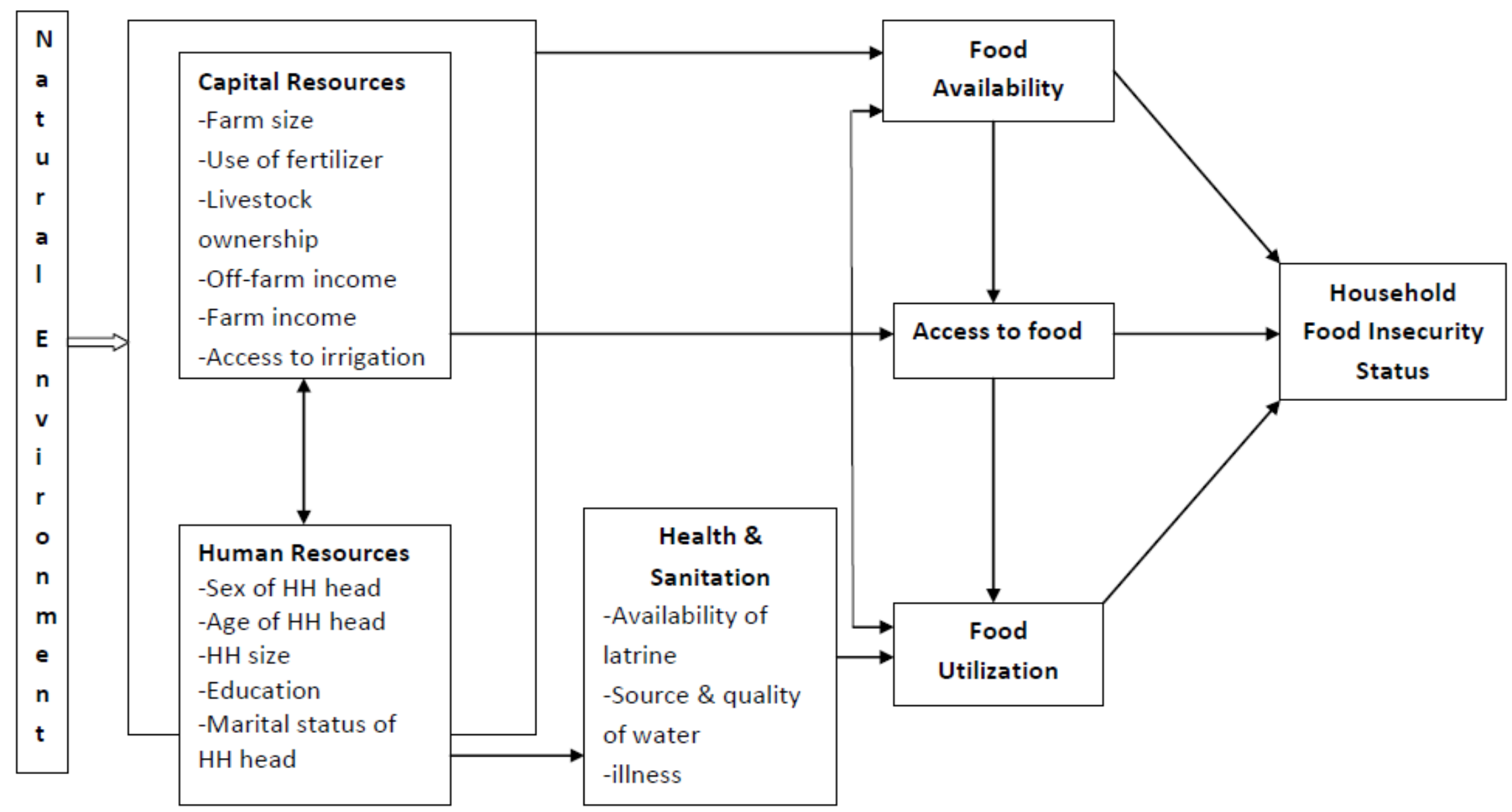

Fig. 1 Conceptual framework for household food insecurity

Adapted from Food Security Information for Action: Food Security Concepts and Frameworks. FAO (2008), with major modification. 


\subsection{Justification of the study}

Reducing food insecurity in the developing world continues to be a major public policy challenge, and one that is complicated by lack of information on the location, severity, and causes of food insecurity. Food security in Ethiopia is dependent on rain fed agriculture. And $45 \%$ of the population is food insecure. An average of about 15 million people is chronically food insecure (most common form of food insecurity). Current poor nutritional and health status indicators are dimension of the presence of high food insecurity in Ethiopia. Adequate, nutritious and safe food is basic precondition for active, healthy and decent life.

As my knowledge is concerned on literature review, there is no previous household food insecurity study conducted on these rural households using HFIAS.

Since large and widely dispersed populations depend on rain fed agriculture and the Ethiopian government implements poverty reduction strategy, assessing food insecurity condition and identifying factors is an important input to promote effective and better directed actions aimed at reducing household food insecurity and poverty for policy implications and interventions. 


\section{Objectives}

\subsection{General objective}

The general objective of this research is to assess the prevalence of household food insecurity and associated factors in rural communities of Gondar City Administration.

\subsection{Specific objectives}

- To determine the prevalence of household food insecurity in rural communities of Gondar City Administration.

- To identify factors affecting household food insecurity in rural communities of Gondar City Administration. 


\section{Methods}

\subsection{Study design}

Community based cross-sectional quantitative study design was carried out in rural households of Gondar City Administration from April to September 2011.

\subsection{Study area}

The study was conducted in rural households of Gondar City Administration which is located in North Gondar Zone, Amhara Regional State, Ethiopia. The selection of the rural Kebeles was based on accessibility and administrative convenience. Gondar is located 748km North West of Addis Ababa and according to the City Administration 2002 E.C base line survey there has been estimated total population of 331,430 of which 42,428 are living in rural kebeles and the rest in urban. Administratively there are 11 rural and 13 urban kebeles in the City Administration. The administration has one government and one private hospitals, 8 health centers and 14 health posts and 33 private clinics rendering health care services for the population.

\subsection{Study population}

All rural households in randomly selected four kebeles were study population and each household selected randomly from the four kebeles using computer generated table of random number was sampling unit.

\section{Exclusion criteria}

Those household that were unable to give information due to illness or hearing difficulty at the time of data collection will be excluded from the study.

\subsection{Sample size determination}

Sample size was determined using a single population proportion formula $n=\frac{\left(\frac{z \alpha}{2}\right)^{2} p(1-p)}{d^{2}}$ on the assumption of $45 \%$ overall prevalence $(P)$ of household food insecurity in rural Amhara Region, at $95 \%$ confidence level $\left(\frac{z \alpha}{2}=1.96\right)$, and $5 \%$ margin of error (d).

Hence, $n=\frac{1.96^{2} x .45(1-.45)}{.05^{2}} \quad n=381$ 
Since the total number of households were less than 10,000 by using correction formula, $n_{f}=\frac{n_{o}}{1+\frac{n_{0}}{N}} \quad$ Where $\mathrm{n}_{0}=$ the above sample size $\& \mathrm{~N}=$ total number of Study population

Then $\quad n_{f}=\frac{381}{1+\frac{381}{2,279}}$

$$
n_{f}=327
$$

By considering the multistage nature of sampling technique the final sample size was multiplied by 2 and finally by adding a 10\% non response rate the required sample size was 720 .

\subsection{Sampling procedures}

A two stage random sampling technique was employed to draw sample households. In the first stage, out of the total eleven kebeles, four kebeles were selected randomly. At second stage, a total of 720 sample household heads were selected after probability proportional allocation of households for each kebele using computer generated table of random number.

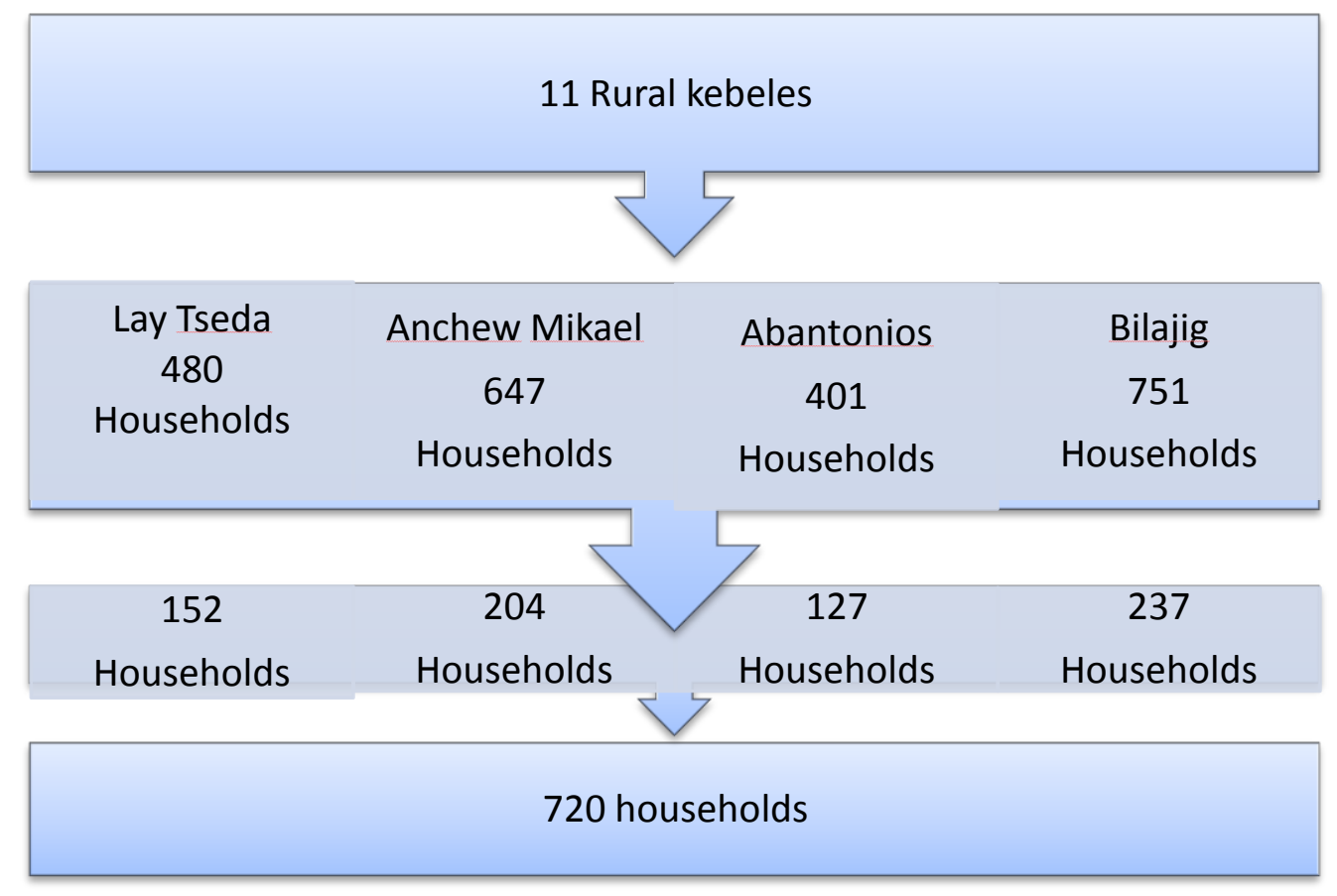

SRS

SRS

Fig.2 Schematic representation of sampling procedure 


\subsection{Data collection procedure}

Household heads and/or individuals who were responsible for food preparaion were used as source of data on behalf of themselves and members of the family. Structured questionnaire was developed based on universally applicable household food insecurity measurement tool. This tool was originally developed by the United States Food and Nutrition Technical Assistance (FANTA) Project targeting at reducing hunger, malnutrition, and food insecurity in the developing world. The reason why this instrument used is because of the challenges in measuring household food insecurity of the technical difficulty and cost of collecting and analyzing data on traditional food security indicators, such as per capital income and caloric adequacy. The HFIAS holds promise as an easier and more user-friendly approach for measuring the access component of household food security.[46]

The HFIAS consists of two types of related questions. The first question type is called an occurrence question. There are nine occurrence questions that ask whether a specific condition associated with the experience of food insecurity ever occurred during the previous four weeks (30 days). Each severity question was followed by a frequency-of-occurrence question, which asked how often a reported condition occurred during the previous four weeks prior to data collection time. [42]

\section{Data collectors}

In this research 8 health extension workers and two public health professionals were participated in data collection and supervision. And the data were collected through door-to-door survey of households starting from June 1 to June 14/2011.

\section{Data quality control}

To ensure the data quality standardized Amharic data collection instruments were used and pre-testing was carried out to check the effectiveness of data collection instrument using $5 \%$ of the sample population in rural households which were not included in the sample. After pretest the questionnaire was standardized for further actual data collection. Data collection manual was also prepared which showed specific data collection specifications and procedures. One day training was given for the research staff on research protocol and data collection instruments. At the

time of data collection, supportive supervision was made and data were reviewed by 
field workers and supervisors. Data were checked before data entry by data manager and data entry personnel.

\subsection{Variables of the study}

3.7.1. Dependent variable:

Household food insecurity

3.7.2. Independent variables:

* Factors associated with human resources

$>$ Sex of household head

$>$ Age of household head

$>$ Household size

$>$ Education of household head

$>$ Marital status of household head

$>$ Ethnicity

$>$ Religion

$>$ Occupation

$>$ Family size

- Factors associated with capital resources

$>$ Farm size

$>$ Fertilizer application

$>$ Livestock ownership

$>$ Off-farm income

$>$ Farm income

$>$ Access to irrigation

$>$ Annual average total income

* Factors associated with health and sanitation

$>$ Availability of latrine

$>$ Source of potable water

$>$ Health status of members of the family 


\subsection{Operational definitions}

- Food availability is the physical presence of food on the market or home.

- Food access is the way households can obtain the available food.

- Food utilization is the way households use the food. [9]

- Household: family members that sleep under the same roof and take meals together at least four days a week.

- Household food security: exists when all households did not have anxiety and uncertainty about the household's food supply or worried rarely and no problem of insufficient quality and insufficient food intake and its physical consequences.

- Mild food insecurity: worries about not having enough food sometimes or often, and/or is unable to eat preferred foods, and/or eats a more monotonous diet than desired and/or some foods considered undesirable, but only rarely.

- Moderate food insecurity: household sacrifices quality more frequently, by eating a monotonous diet or undesirable foods sometimes or often, and/or has started to cut back on quantity by reducing the size of meals or number of meals, rarely or sometimes.

- Severe food insecurity: households has graduated to cutting back on meal size or number of meals often, and/or experiences any of the three most severe conditions (running out of food, going to bed hungry, or going a whole day and night without eating), even as infrequently as rarely.

- Household food insecurity: having anxiety and uncertainty about the household's food supply or worried sometimes or often or households experience problems of insufficient quality of food or insufficient food intake or its physical consequences. [47]

- Family size: it refers to the total number of household members who lived and ate with household head for at least six months and more.

- Farm size: it refers to the cultivated farmland in hectare (owned, shared and rented) allocated for annual and perennial crops, vegetable and for homestead farming activities. 
- Off-farm income: it is annual off-farm and/or non-farm income in Birr (Ethiopian national currency, during the survey time) that a household heads or his family members earn from off-farm activities.

- Livestock owned: is the total livestock (cattle, equines, sheep, goat, and chicken) owned by a household.

- Farm income: is the total annual income earned from crop and livestock sale.

\subsection{Data management}

Possible responses of variables were coded before actual data collection began. Epi Info Version 3.5.1 for data entry and SPSS version 16 and STATA Computer programs for data analysis were used. Before data analysis thorough data cleaning activities were performed.

\subsection{Data processing and analysis}

After the collection of all the necessary data, it was coded on pre-arranged sheet by the principal investigator. Data were thoroughly cleaned before entry. The responses from the household food insecurity measure were entered into computer using statistical software Epi Info Version 3.5.1 and analyzed by the use of SPSS version 16 (for descriptive statistics and logistic regressions) and STATA (for determining household food insecurity categories) computer software.

Household food insecurity status was calculated based on Household Food Insecurity Access Scale recommended by USAID. The household's socio-economic characteristics were described using descriptive statistics of frequency and percentage distribution tables. To determine factors significantly associated with household food insecurity, binary logistic regression analyses were employed and their odds ratios, confidence intervals and $p$-values were also obtained. In the backward stepwise (Likelihood Ratio) approach variables were selected one at a time, and at each step. 


\section{Ethical considerations}

Ethical clearance was obtained from University of Gondar College of Medicine and Health Sciences School of Public Health. Official letter of cooperation was also written to each rural kebeles by Gondar City Administration Health Office. Following having permission from kebele administrations, informed consent was obtained from each household after clear explanation about the purpose of the study. Confidentiality of the information was also assured by the use of ID variables from the questionnaire. 


\section{Results}

\subsection{Socio-economic characteristics of household heads}

The socio-demographic characteristics of household heads are summarized in Table 1. A total of 720 households were included in the study with non-response rate of $6(0.83 \%)$. The number of male household heads $527(73.8 \%)$ was higher than the number of female household heads $187(26.2 \%)$. The Mean age of the heads was $46.53 \pm 15.1$ years. Most household heads $(27.3 \%)$ were found in the age group of 30-39. On average there were 5.27 persons per household and $315(44.1 \%)$ of the households had more than 5 family members. A significant proportion of heads (73.8\%) were married and $99.0 \%$ were orthodox by religion. As to the primary occupation, Most $(87.3 \%)$ of house hold heads were farmers and more than half of them $(65 \%)$ have never attended any form of education 
Table 1. Socio-demographic characteristics of household heads in rural community of Gondar City Administration, 2011.

\begin{tabular}{|c|c|c|}
\hline Characteristics & Frequency & Percent \\
\hline Male & 527 & 73.8 \\
\hline Female & 187 & 26.2 \\
\hline \multicolumn{3}{|l|}{ Age } \\
\hline $18-20$ & 3 & 0.4 \\
\hline $21-24$ & 13 & 1.8 \\
\hline $25-29$ & 55 & 7.7 \\
\hline $30-39$ & 195 & 27.3 \\
\hline $40-49$ & 166 & 23.2 \\
\hline $50-59$ & 124 & 17.4 \\
\hline$\geq 60$ & 158 & 22.1 \\
\hline \multicolumn{3}{|l|}{ Marital status } \\
\hline Single & 37 & 5.2 \\
\hline Married & 527 & 73.8 \\
\hline Divorced & 55 & 7.7 \\
\hline Widowed & 95 & 13.3 \\
\hline \multicolumn{3}{|l|}{ Religion } \\
\hline Orthodox & 707 & 99 \\
\hline Muslim & 5 & 0.7 \\
\hline Catholic & 2 & 0.3 \\
\hline \multicolumn{3}{|l|}{ Education } \\
\hline Illiterate & 467 & 65.4 \\
\hline Reading and writing & 150 & 21 \\
\hline Primary & 46 & 6.4 \\
\hline Secondary & 45 & 6.3 \\
\hline Above secondary & 6 & 0.8 \\
\hline \multicolumn{3}{|l|}{ Occupation } \\
\hline Farmer & 623 & 87.3 \\
\hline Student & 7 & 1.0 \\
\hline Small scale merchant & 7 & 1.0 \\
\hline Civil servant & 7 & 1.0 \\
\hline Daily laborer & 58 & 8.1 \\
\hline Small scale group work & 4 & 0.6 \\
\hline \multirow{2}{*}{\multicolumn{3}{|c|}{ Family size }} \\
\hline & & \\
\hline $1-3$ & 173 & 24.2 \\
\hline $4-6$ & 336 & 47.1 \\
\hline 7-9 & 173 & 24.2 \\
\hline $10-12$ & 32 & 4.5 \\
\hline
\end{tabular}




\section{Housing conditions and household assets in the study area}

In the study area the majority of the houses, 690 (96.6\%), had a roof made of iron sheet, and $24(3.4 \%)$ were made of thatch. The floor material for the majority of households was made of mud and cow dung (99\%). More than $89 \%$ of the households had reported that they have separate place for domestic animals to spend the night where as in $10.2 \%$ of households animals spend the night with members in the same house. Households having livestock were found to be $589(82.5 \%)$ in number. Specifically $547(76.6 \%)$ and $263(36.8 \%)$ of households reported that having cattle and sheep or goats respectively. $529(74.1 \%)$ of households have chickens. From the total households, only $216(30.3 \%)$ of them possessed radio and $10(1.4 \%$ ) had access to television (Table 2).

Table 2. Housing conditions and household assets in rural communities of Gondar City Administration, 2011.

\begin{tabular}{lrrr}
\hline Characteristics & \multicolumn{1}{c}{ Prevalence } & Percent \\
\hline Floor & Mud/ cow dung & 707 & 99.0 \\
& Wood & 5 & 0.7 \\
& Cement & 2 & 0.3 \\
Roof & Thatch & 24 & 3.4 \\
& Corrugated iron sheet & 690 & 96.6 \\
Animals share house & & & \\
& Yes & 73 & 10.2 \\
Livestock owned & No & 641 & 89.8 \\
& & & \\
\multirow{4}{*}{ Foul owned } & Yes & 589 & 82.5 \\
& No & 125 & 17.5 \\
Radio & & & \\
& Yes & 530 & 74.2 \\
Television & No & 184 & 25.8 \\
& Yes & 216 & 30.3 \\
& No & 498 & 69.7 \\
& Yes & 10 & 1.4 \\
& No & 704 & 98.6 \\
\hline
\end{tabular}




\section{Farm related characteristics of the study area}

Table 3. Farm related characteristics of households in rural communities of Gondar City Administration, 2011.

\begin{tabular}{lrrr}
\hline Characteristics & Prevalence & Percent \\
\hline Access to farm land & & & \\
& Yes & 650 & 91 \\
& No & 64 & 9 \\
& Total & 714 & 100
\end{tabular}

Farm size (ha)

$\begin{array}{rrr}0.10-0.50 & 141 & 21.7 \\ 0.51-1.00 & 288 & 44.3 \\ 1.01-2.00 & 191 & 29.4 \\ 2.01-5.00 & 30 & 4.6 \\ \text { Total } & 650 & 100\end{array}$

Access to irrigation

Fertilizer used

$\begin{array}{rrr}\text { Yes } & 155 & 21.7 \\ \text { No } & 559 & 78.3 \\ \text { Total } & 714 & 100\end{array}$

Annual crop production (quintal per $\mathrm{HH}$ )

$\begin{array}{crr}\text { Yes } & 607 & 93.4 \\ \text { No } & 43 & 6.6 \\ \text { Total } & 650 & 100\end{array}$

$\begin{array}{rrr}0.6-4.0 & 112 & 17.2 \\ 4.1-7.5 & 261 & 40.2 \\ 7.6-11.0 & 135 & 20.8 \\ 11.1-14.5 & 88 & 13.5 \\ >14.5 & 54 & 8.3 \\ \text { Total } & 650 & 100\end{array}$

Average monthly off-farm income

(Eth. Birr per HH)

$\begin{array}{rrr}<423.5 & 175 & 72 \\ \geq 423.5 & 68 & 28 \\ \text { Total } & 243 & 100\end{array}$

Annual Farm income

(Eth. Birr per HH)

$\begin{array}{lll}<5,257.7 & 401 & 56.2 \\ \geq 5,257.7 & 313 & 43.8\end{array}$

Total annual income

(Eth. Birr per HH)

$\begin{array}{lll}<6,987 & 442 & 61.9 \\ \geq 6,987 & 272 & 38.1\end{array}$


As shown in Table 3 above in the study kebeles $650(91 \%)$ of households were reported having farm land to cultivate which is either rented or owned by the household. And mean farm size of households was found to be 1.0 hectare. Out of those households which have farm land only $21 \%$ of them have access to irrigation. Almost above $93 \%$ of households with farmland used fertilizers. Of these, $573(94.4 \%)$ used artificial fertilizer, while $12(2 \%)$ applied only natural fertilizer, and the rest $22(3.6 \%)$ used both types of fertilizers. Majority $(59.7 \%)$ of households earned less than mean annual crop production (7 quintals). Among 243 households which had income from off-farm activities such as petty trade, selling fire wood and labor market, on average $72 \%$ of households earned less than the mean (423.5 birr) (Ethiopian National Currency, during the survey time it had an official exchange rate of 1 US $\$=16.84$ birr). Concerning on farm income, income from crop production and animal sell, the majority of households (56.2\%) earned less than the mean $(5,257.7$ Eth. birr) annually. Additionally, almost $62 \%$ of households in the study area earned less than the mean total average annual income (6,987 Eth. birr).

\section{Water and sanitary conditions}

The source of drinking water used by $214(30 \%), 343(48 \%), 88(12.3 \%)$ and $27(3.8 \%)$ of the households were pipe water, protected spring, unprotected spring and river respectively. About $163(22.8 \%)$ of households require 31-60 minutes to fetch water from the sources and the other $76(10.6 \%)$ require greater than one hour. As shown in Table 4, 293(41\%) of households in the study area did not have any kind of latrine as a result household members go to bushes or open field for defecation. In the study area only $47.1 \%$ of household heads had the experience of washing their hands after defecation of feces but $34 \%$ and $18.1 \%$ of heads did not have hand washing habits not at all and sometimes, respectively. Most of the time $84.2 \%$ of households experience garbage disposal mechanisms in the surrounding for fertilizer use. As indicated in table 4 , about $72 \%$ of households had reported the experience of having insects like bedbug, flea, lice, mosquitoes, ginger flea and cockroach. 
Table 4. Water and sanitary conditions of households in rural communities of Gondar City Administration, 2011.

\begin{tabular}{|c|c|c|}
\hline Characteristics & Prevalence & Percent \\
\hline \multicolumn{3}{|l|}{ Source of drinking water } \\
\hline Pipe & 214 & 30 \\
\hline Protected spring & 343 & 48 \\
\hline Protected well & 32 & 4.5 \\
\hline Unprotected spring & 88 & 12.3 \\
\hline Únprotected well & 10 & 1.4 \\
\hline River & 27 & 3.8 \\
\hline \multicolumn{3}{|l|}{ Water collection material } \\
\hline Jerry can & 707 & 99 \\
\hline Iron bucket & 5 & 0.7 \\
\hline & 2 & 0.3 \\
\hline \multicolumn{3}{|l|}{$\begin{array}{l}\text { Time required to fetch water } \\
\text { (minutes) }\end{array}$} \\
\hline $1-15$ & 287 & 40.2 \\
\hline $16-30$ & 188 & 26.3 \\
\hline $31-60$ & 163 & 22.8 \\
\hline$>60$ & 76 & 10.6 \\
\hline \multicolumn{3}{|l|}{ Availability of latrine } \\
\hline Yes & 421 & 59 \\
\hline No & 293 & 41 \\
\hline \multicolumn{3}{|l|}{ Type of latrine } \\
\hline Pit latrine with shelter & 341 & 81 \\
\hline Pit latrine without shelter & 80 & 19 \\
\hline Total & 421 & 100 \\
\hline \multicolumn{3}{|l|}{$\begin{array}{l}\text { Hand washing habit after } \\
\text { defecation }\end{array}$} \\
\hline Always & 336 & 47.1 \\
\hline Sometimes & 135 & 18.9 \\
\hline Never & 243 & 34 \\
\hline \multicolumn{3}{|l|}{ Garbage disposal } \\
\hline Pit & 30 & 4.2 \\
\hline Purposely prepared place & 18 & 2.5 \\
\hline Open field & 65 & 9.1 \\
\hline In the surrounding for fertilizer & 601 & 84.2 \\
\hline \multicolumn{3}{|l|}{ Animal share house } \\
\hline Yes & 73 & 10.2 \\
\hline No & 641 & 89.8 \\
\hline \multicolumn{3}{|l|}{ Presence of vectors } \\
\hline Yes & 516 & 72.3 \\
\hline No & 198 & 27.7 \\
\hline
\end{tabular}




\subsection{Household food insecurity level of the study area}

In the study area respondents of the households were interviewed for the experience of events in the previous four weeks that were associated with food insecurity. Accordingly, $45.1 \%$ of them have reported to have worried for enough food may not be available in the house during the specified period of time. The frequency of not eating preferred foods, eating limited variety of foods, eating foods that were not preferred and eating a small amount of food was found to be $45.9 \%, 50.7 \%, 36.8 \%$ and $33.8 \%$, respectively. Almost $85 \%$ of households have reported that there was no problem of ever no food and members of the household sleep hungry at night.

Table 5. Food insecurity condition of households in in rural communities of Gondar City Administration, 2011.

Characteristics

Frequency

Percent

HH worried for not having enough food

HH not eaten preferred food ${ }^{*}$

Yes

322

45.1

HH ate limited variety of food

No

386

54.1

Yes

328

45.9

HH forced to eat foods that are not
preferred $^{\star \star}$

$\begin{array}{rrr}\text { No } & 352 & 49.3 \\ \text { Yes } & 362 & 50.7\end{array}$

$$
\text { Yes }
$$

HH have to eat small amount of food

No $\quad 451$

Yes

263

36.8

No

473

66.2

241

33.8

HH have to eat fewer meals in a day

$$
\text { Yes }
$$

No

527

73.8

Yes

187

26.2

$\mathrm{HH}$ in which there was ever no food

606

84.9

108

15.1

HH members sleep hungry at night

$\begin{array}{rr}\text { No } & 606 \\ \text { Yes } & 108\end{array}$

85.3

Yes

HH members go the whole day without

609

105

14.7 eating anything

No

678

95

36 
N.B: * mean foods that food secure people eat. E.gs Meat, Egg, Milk, etc.

** mean foods like Sorghum 'Enjera', Boild grains (Nifro), Roasted grains (Kollo), and the like.

Using HFIAS, the food insecurity level of households was calculated to be $280(39.2 \%), \quad 120(16.8 \%), 162(22.7 \%)$ and $152(21.3 \%)$ food secured, mildly insecure, moderately insecure and severely insecure, respectively.

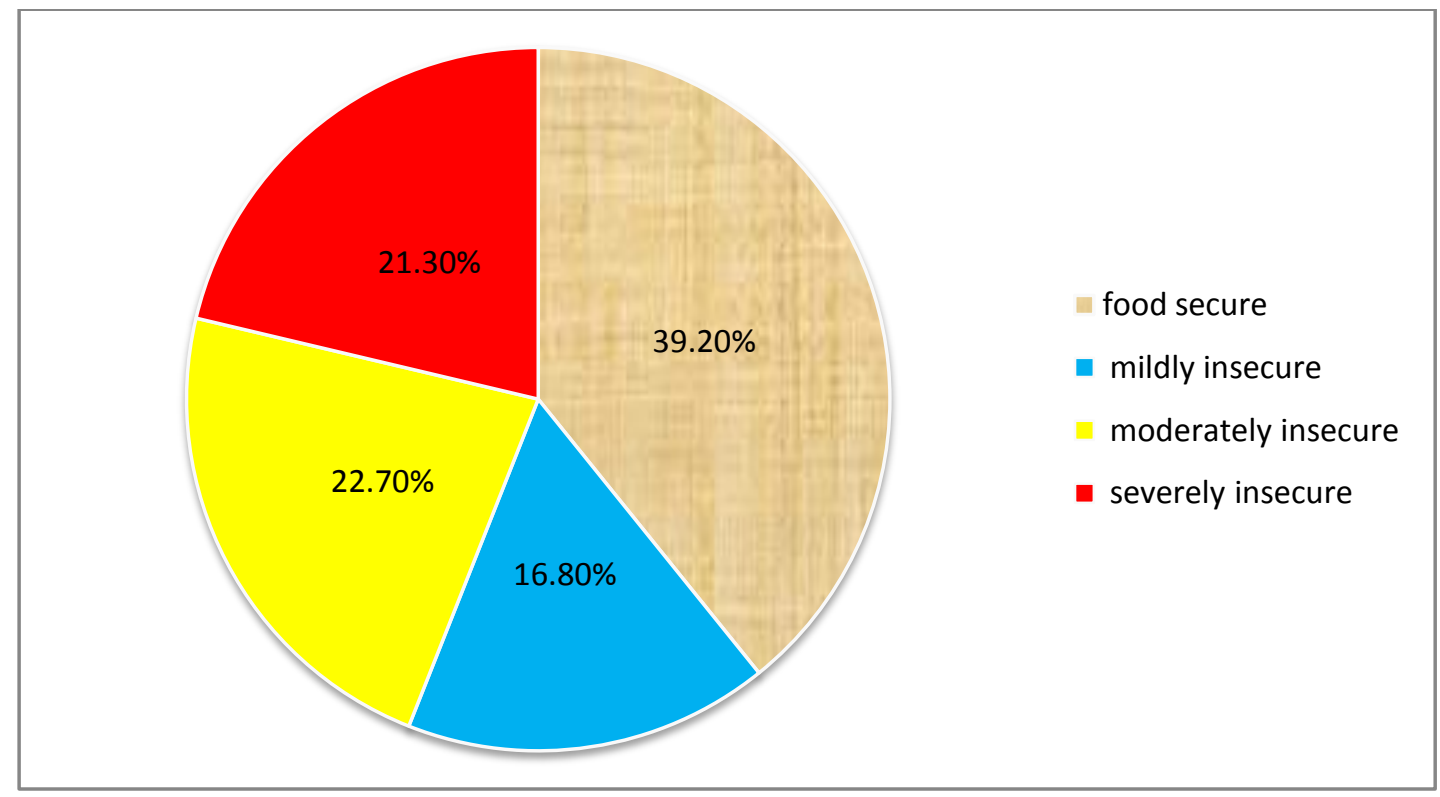

Fig. 3 Food insecurity status in rural communities of Gondar City Administration, 2011

In the study area, the overall prevalence of household food insecurity was found to be $60.8 \%$. $59 \%$ of male headed households were food insecure while in females it was $65.8 \%$. Relatively the proportion of household food insecurity in the age range of $18-39$ was high (67.3\%). It was found that 173 of the sample households had 3 or less than 3 members out of which $68.8 \%$ were found to be food insecure. On the other hand, out of the 205 households who had greater than 6 members $56.6 \%$ were found to be food insecure.

When we come to the socio-economic predictors, among the household heads those were illiterate, $59.5 \%$ are food insecure while in those household heads those could read and write it is $63.2 \%$. It was also found that $59.2 \%$ of married and $80 \%$ of divorced household heads were found to be food insecure. Concerning on 
occupation, food insecurity was found to be $83 \%$ in other than farming occupation and $57.5 \%$ in farmers.

An attempt was also made to examine the involvement of households in non-farm activities. It was found that about 242 households were engaged in non-farm activities out of which $67.8 \%$ of them were food insecure. On the other hand out of 472 households which do not have income from non-farm activities, $57.2 \%$ of them were food insecure. Among households that had farm land, and those who hadn't, $58.2 \%$ and $87.5 \%$ of them were found to be food insecure, respectively. $71.6 \%$ of households having farm land size of $0.10-0.50$ ha were food insecure while in those that had greater than 2 ha household food insecurity is found $13.3 \%$.

\subsection{Factors associated with household food insecurity status}

Bivariate analysis of each predictor variables against the household food insecurity status was performed to identify the significant candidate predictor variables that would qualify for the multivariate analysis. The major factors that were expected to determine household food insecurity status were first analyzed by considering the relationship of each predictor variable with the outcome variable. Twelve of the fifteen explanatory variables considered in this study were found statistically significant with the status of household food insecurity $(p<0.05)$. The results of these logistic regression analyses showed that age, marital status, and occupation of household heads, family size, farm size, irrigation, fertilizer, livestock owned, farm income, total monthly income, source of drinking water and availability of latrine were found to be statistically significant in explaining household food insecurity. On the other hand variables like sex, education and off-farm income of household heads were not statistically significant.

Table 6 provides six predictors, out of the nine variables, which were initially included in logistic regression model (multivariate analysis). 
Table 6. Logistic regression of household food insecurity with predictor variables in rural communities of Gondar City Administration, 2011.

\begin{tabular}{|c|c|c|c|c|c|}
\hline \multirow{2}{*}{$\begin{array}{l}\text { Predictor } \\
\text { Variables }\end{array}$} & \multicolumn{2}{|c|}{ Food insecurity } & \multirow[b]{2}{*}{ COR(95\% Cl) } & \multirow[b]{2}{*}{ AOR(95\% Cl) } & \multirow{2}{*}{$\begin{array}{c}\text { P- } \\
\text { value }\end{array}$} \\
\hline & Yes & No & & & \\
\hline \multicolumn{6}{|l|}{ Livestock } \\
\hline Yes* * $^{*}$ & 325 & 264 & & & \\
\hline No & 109 & 16 & $5.53(3.195,9.585)$ & $2.05(1.039,4.022)^{\star}$ & 0.038 \\
\hline \multicolumn{6}{|l|}{ Fertilizer } \\
\hline Yes $^{* *}$ & 337 & 270 & & & \\
\hline No & 97 & 10 & $7.77(3.975,15.193)$ & $4.23(1.741,10.275)^{\star}$ & 0.001 \\
\hline Source of water & & & & & $<0.001$ \\
\hline Pipe** & 126 & 88 & & & \\
\hline Protected spring & 200 & 143 & $0.98(0.691,1.382)$ & $1.27(0.826,1.959)$ & \\
\hline Protected well & 24 & 8 & $2.10(0.900,4.879)$ & $3.08(1.054,8.989)^{*}$ & 0.040 \\
\hline Unprotected spring & 65 & 23 & $1.97(1.141,3.414)$ & $4.00(2.060,7.764)^{\star}$ & $<0.001$ \\
\hline Unprotected well & 3 & 7 & $0.30(0.075,1.189)$ & $1.16(0.224,6.004)$ & \\
\hline River & 16 & 11 & $1.02(0.450,2.294)$ & $3.47(1.323,9.116)^{\star}$ & 0.011 \\
\hline \multicolumn{6}{|l|}{$\begin{array}{l}\text { Off-farm } \\
\text { income }\end{array}$} \\
\hline$<423.5$ & 400 & 246 & $1.63(0.985,2.684)$ & $2.90(1.249,6.712)^{\star}$ & 0.013 \\
\hline$\geq 423.5^{\star *}$ & 34 & 34 & & & \\
\hline \multicolumn{6}{|l|}{ Annual Farm } \\
\hline \multicolumn{6}{|l|}{ income } \\
\hline$<5,257.7$ & 326 & 75 & $8.25(5.858,11.621)$ & $3.98(2.514,6.303)^{\star}$ & $<0.001$ \\
\hline$\geq 5,257.7^{\star \star}$ & 108 & 205 & & & \\
\hline \multicolumn{6}{|l|}{ Total annual } \\
\hline \multicolumn{6}{|l|}{ Income } \\
\hline$<6,987$ & 348 & 94 & $8.01(5.686,11.276)$ & $3.93(2.471,6.258)^{*}$ & $<0.001$ \\
\hline$\geq 6,987^{\star *}$ & 86 & 186 & & & \\
\hline
\end{tabular}

Footnote: * shows statistical significance at $p$-value $<0.05,{ }^{* *}$ shows reference category.

The adjusted logistic regression final model shows fertilizer used, source of drinking water, off-farm income, annual farm income and total average annual income have 
significant association with household food insecurity in the study area. In the above table, households with no livestock possession were 2 times more likely to be food insecure than households owned livestock $(A O R=2.05,95 \% \mathrm{Cl}=1.039-4.022)$. With regard to fertilizer, households that did not apply it on their cultivated farm land are found to be almost 4 times more likely to be food insecure than those that apply it $(\mathrm{AOR}=4.23,95 \% \mathrm{Cl}=1.741-10.275)$. Similarly households that collected drinking water from unprotected springs are 4 times more likely to be food insecure than those that collected from piped water sources $(A O R=4.00,95 \% \mathrm{Cl}=2.060-7.764)$.

The logistic regression result (Table 6) revealed that households which had less than the mean average monthly off-farm income of 423.5 Eth. birr are 3 times more likely to be food insecure than households with an average off-farm income of greater than or equal to the mean $(\mathrm{AOR}=2.90,95 \% \mathrm{Cl}=1.249-6.712)$. Regarding annual farm income, averagely households earned less than 5,257.7 Eth. birr are almost 4 times more likely to be food insecure than those households whose average annual farm income was greater than or equal to 5,257.7 Eth. birr (AOR = $3.98,95 \% \mathrm{Cl}=2.514-6.303)$. It is also noticed that households that had total average annual income of less than 6,987 Eth. birr are almost 4 times more likely to be food insecure than those that had greater than or equal to it $(A O R=3.93,95 \% \mathrm{Cl}$ $=2.471-6.258$ ). 


\section{Discussion}

\subsection{Food insecurity status of households}

The result of this study revealed that $280(39.2 \%), 120(16.8 \%), 162(22.7 \%)$ and $152(21.3 \%)$ of households were food secured, mildly insecure, moderately insecure and severely insecure respectively. This finding differs from the result of a cross sectional study conducted in selected woredas of four Regions: Amhara, Oromia, SNNP and Tigray Regions using HFIAS, which showed that the food insecurity level of rural households was found to be $6(0.6 \%)$ food secured, $42(4.1 \%)$ mildly insecure, 404(39.9\%) moderately insecure, and 561(55.4\%) are severely insecure respectively.[30] This may be due to the difference in agro-ecological area, sampling procedure and socio-economic composition. On the other hand the prevalence of household food insecurity is partially consistent with another finding conducted in rural Tajikistan in which household food insecure status is $12 \%, 22 \%$ and $66 \%$ severely food insecure, moderately food insecure and food secure respectively.[24]

The overall prevalence of household food insecurity was found to be $60.8 \%$ in the study area. This is higher than the prevalence of household food insecurity reported in rural Tanzania, 36\% of households were food insecure in 2005.[23] The possible reasons for this difference may be difference in demographic, socio-economic and cultural characteristics. The result is also greater than another study conducted in rural Amhara in which household food insecurity was 45\%.[26] This may be due to the use of distinct household food insecurity measurement tools and the data collected in different geographical area and socio-economic characteristics.

On the other hand this finding is lower than the results of different studies conducted in Ethiopia such as rural Dire Dawa and SNNP (Bilate watershed that transects Hadiya, Kembata Tembaro, Wolaita and Sidama zones and Alaba district) in which household food insecurity was found to be a severe problem with $76 \%$ and $73 \%$ respectively.[27, 28] This may be due to the difference in distinct agro-climatic zones and socio-economic characteristics. 


\subsection{Factors associated with household food insecurity}

Livestock production plays an indispensable role in the mixed farming operation. Of the different livestock species in this production system, cattle, sheep, goats, and foul are used to generate income in the study area. Households with no livestock possession were 2 times more likely to be food insecure than households owned livestock. Similar studies conducted in Burkina Faso, Amhara and Southern Ethiopia regions revealed livestock as an indicator of wealth, source of income to purchase food and non food items, had a significant and negative impact on the household food insecurity status. [26,28,36]

Result of the multivariate analysis (Table 6) showed that use of fertilizer is one of the factors which were found to have a significant impact on household food insecurity in the study area. Use of fertilizer was found an important factor in enhancing crop production, which in turn minimizes household's food insecurity status. Non-Fertilizer user households in comparison with fertilizer user households were higher in food insecurity status. This finding is in line with studies conducted in Oromiya Zone, Dire Dawa and Southern Ethiopia.[28,39,40]

For unsafe potable water sources the likely probability to become food insecure is high compared with safe water sources. The finding of this research is supported by literatures in Cambodia and Eritrea which stated that insufficient access to safe water sources and hygienic toilets in rural villages has strong linkages to the use of food and is a basic obstacle to improved food security and nutrition and the achievement of the MDGs.[37,38]

Petty trade, selling local beverage ("Tella"), tea, and firewood and working in government sectors, working in small scale organizations and working as daily laborer activities are sources of off-farm income. Since it is linked with food consumption it can be used as an alternative means to improve the level of household food insecurity. In the study area off-farm income provides cash to buy food grains and non-food items required for household members. Thus it was found 
that off-farm income is significantly associated with household food insecurity. As monthly off-farm income earned by households increase, food insecurity decrease. This finding is supported by studies conducted in Ghana, Amhara and Southern Ethiopia which concluded that off-farm income increases the odds of food insecurity.[26,28,34] The possible reason for this similarity may be due to off-farm income could be used as an alternative means of income to full fill household food supply in rural areas of Africa.

A strong significant association exists between annual farm income and household food insecurity status in the study area. Households earned low annual farm income were more likely to become food insecure than those households who had higher farm income. Similarly studies in rural Nigeria, Amhara and Southern Ethiopia supports that farm income influences negatively household food insecurity. [26, 32]

In the study area people derive income from multiple sources-both from farm and non-farm sources. The sources of these incomes are off-farm activity, income from crop production, and income from livestock sell. Increased income enables rural households to purchase variable agricultural inputs for subsistence crop production, which increase the productivity. It there by, increases the availability of food for consumption at household level. Furthermore, this increased income can also increase their asset base through saving their income in the form of livestock and other household assets and this lead households to be safe in the case of shortage of food where the farmers able to sale their asset and generate income to purchase food items. So that an increase in total household annual income would result in a decrease in the probability of the household being food insecure. This finding is in line with studies conducted in Southern Nigeria, Southern Ethiopia, Eastern Oromia and Dire Dawa. [28, 32, 39, 40]

Generally, despite disparate measurement strategies, nearly all studies suggest a high prevalence of food insecurity, an important finding as the experience of food insecurity, has been associated with a range of factors, including fertilizer 
application, source of drinking water, farm income and total annual average income of households.[29,30,35,36] This idea is also supported by the result of this finding which has similar consensus.

Limitation: Problems have been faced during data collection process. These problems were associated with farmers' attitude of being suspicious, food aid expectation and limited time of data collection period. Since farmers do not keep records their income and the information needed the collected data is very much dependent on his/her ability to remember what they did within a year prior to data collection. Therefore, in order to minimize the problem the interview was conducted in the presence of the most knowledgeable members of the family. Another problem, which was observed, was farmers suspicious to tell the right information especially with regard to their annual production and land size because of fear of taxation. In order to minimize this problem, data collectors were taking some time to explain the purpose of the survey before starting the interview. 


\section{Conclusion}

Based on the data collected from rural communities of Gondar City Administration and the analyses made, the following conclusions are drawn:

- The results of the study revealed that the majority of households in rural communities of Gondar City Administration are food insecure.

- Livestock ownership determines household food insecurity either through income earning or by direct consumption.

- Households that do not use technologies like fertilizers for their cultivated farm lands are tend to be food insecure.

- Lack of diversified income generating mechanisms leads rural households to produce food on small plot of land with poor agricultural technologies. In such circumstances, the current food insecurity at the local level persists and might push influx of people to migrate to the nearby urban areas.

- Farm income is one of the most significant determinants that affect household food insecurity status negatively in the study area.

- Total annual average income is also one of the major factors which affect household food insecurity negatively in rural communities of Gondar City Administration.

In general, with reference to base group of food secure households, it is concluded that lack of livestock ownership, non-use of fertilizers, having unsafe potable water sources, lack of or minimized off-farm income, decreased annual farm income, and reduced total monthly household income are significantly associated with household food insecurity and increase the likelihood of households to be food insecure in the study area. 


\section{Recommendation}

As rural part of Gondar City Administration is facing higher prevalence of food insecurity which is associated with different factors, the following recommendations are forwarded:

- In view of the negative impact of unsafe potable water sources on the food insecurity situation of rural households in the study area, Gondar City Administration Rural Potable Water Sector Office in collaboration with Non Governmental Organizations should design strategies to improve the overall quality and quantity of water supply in the study area.

- The livestock sub-sector should be enhanced through the provision of better husbandry and management system, and better veterinary facilities by the City Administration Agricultural office in collaboration with rural households.

- Modern technologies including fertilizer application shall be used by all rural households in collaboration with Federal Ministry of Agriculture, Regional and Zonal Agricultural Bureaus and Gondar City Administration Agricultural Office in order to maximize crop production and then to minimize food insecurity.

- The City Administration Agricultural Office should support the rural community to Increase the productivity of crops through the provision of farm land, education to farmers, and application of important agricultural inputs and technologies to increase annual farm income.

- It should be noted that the regional government and Gondar City Administration should integrate development of the rural sector, and introduction of various offfarm activities.

- Finally, it is recommended to conduct a study that compares status of food insecurity in rural households with urban households and its associated factors in the City Administration. 


\section{References}

1. Human Development Report 2007/2008. United Nations Development Program; New York: 2007.

2. World Food Program (WFP). Nutrition Consultancy Report on WFP EMOP 6143 and EMOP 6080. Addis Ababa: WFP; 1999.

3. Food Security Program Monitoring and Evaluation Plan: The Federal Democratic Republic of Ethiopia Food Security Coordination Bureau; Oct.2004Sept; 2009.

4. Frank E. Gender, Agricultural Development and Food Security in Amhara, Ethiopia: The Contested Identity of Women Farmers in Ethiopia USAID; 1999 Oct.

5. Gondar [Internet] 2011 Feb; Cited 2011 Apr 5. Available from: http://www.en.wikipedia.org/wiki/Gondar.

6. Kaluski D, Ophir E, AmedeT. Food security and nutrition - the Ethiopian case for action; Public Health Nutrition: Telavive. 2001, 5(3), 373-381.

7. Stamoulis K. Food, Agriculture and Rural Development: Current and Emerging Issues for Economic Analysis and Policy Research. Rome, Italy: Food and Agriculture Organization of the United Nations; 2001.

8. Bogale A, Shimelis A. Household Level Determinants of Food Insecurity In Rural Areas Of Dire Dawa, Eastern Ethiopia: African Journal of Food, Agriculture, Nutrition and Development; VoL. 9, No. 9, 2010, PP. 1914-1926.

9. Food security: understanding and meeting the challenge of poverty: European Commission; Belgium, October 2009.

10. Habicht J, Pelto G, Frongillo E, Rose D. Conceptualization and Instrumentation of Food Insecurity. Cornell and Tulane Universities: 2004 Jul.

11. How to conduct a food security assessment: A step-by-step guide for National Societies in Africa. $2^{\text {nd }}$ ed. International Federation of Red Cross and Red Crescent Societies. Geneva. 2006.

12. The State of Food Insecurity in the World 2001. FAO: Rome. 2002 pp. 4-7. 
13. Bickel G, Nord M, Price C, Hamilton W, Cook J. Guide to Measuring Household Food Security. U.S. Department of Agriculture: Food and Nutrition Service. Alexandria VA: 2000 Mar.

14. Andersen P. Food security: definition and measurement. Springer Science. 2009 Jan; 1:5-7.

15. Food and Nutrition Technical Assistance Project. Measuring Household Food Insecurity Workshop II Report October 19, 2005. Washington, D.C., Academy for Educational Development, 2005.

16. Maes K, Hadley C, Tesfaye F, Shifferaw S, Tesfaye Y. Food Insecurity among Volunteer AIDS Caregivers in Addis Ababa, Ethiopia Was Highly Prevalent but Buffered from the 2008 Food Crisis. The Journal of Nutrition: the American Society for Nutrition.2009 Jul.

17. The State of Food Insecurity in the World. Addressing food insecurity in protracted crises: Food and Agriculture Organization of the United Nations. Rome; 2010.

18. Nelson M, Erens B, Bates B, Church S, Boshier T. Low Income Diet and Nutrition Survey. London: Food Standards Agency; 2007.

19. Ministry of Health. NZ Food: NZ Children: Key Results of the 2002 National Children's Nutrition Survey. Wellington: Ministry of Health; 2003.

20. Nord M , Hooper M, Hopwood H. 'Household-Level Income-Related Food Insecurity is Less Prevalent in Canada than in the United States', Journal of Hunger \& Environmental Nutrition, 2008; 3: 1, 17 - 35.

21. Nord M, Andrews M, Carlson S. Household Food Security in the United States, 2008. Washington, DC: U.S. Department of Agriculture Economic Research Service; 2009.

22. Gopichandran V, Claudius P, Baby LS, Felinda A, Mohan VR. Household food security in urban Tamil Nadu: a survey in Vellore. Tamil Nadu, India. Natl Med J India. 2010 Sep-Oct; 23(5):278-80.

23. Hadley C, Patil C. Food Insecurity in Rural Tanezania Is Associated with Maternal Anxiety and Depression. American Journal of Human Biology; 2006; 18:359-368. 
24. Emergency Food Security Assessment in Rural Areas of Tajikistan: A Joint Food Security, Livelihoods, Agriculture and Nutrition Assessment. WFP, FAO, UNICEF and Government of Tajikistan; 2008 April/May.

25. Schmidt E, Dorosh P. A Sub-National Food Security Index for Ethiopia: Assessing Progress in Region-Level Outcomes. International Food Policy Research Institute - Ethiopia Strategy Support Program; 2009 Oct.

26. Seid F. Food Insecurity and Its Determinants in Rural Households in Amhara Region. FBAE, Addis Ababa University. Accessed at www.edri.org.et/december 2007 Feb.

27. Shimelis A, Bogale A. Dimensions of food insecurity and livelihood strategies among rural households in Dire Dawa, eastern Ethiopia. InterScience Wiley; Tropical Science; 2007 Jun 27; 47(2), 73-80.

28. Tsegaye G, Bekele W. Farmers' perceptions of land degradation and determinants of food security at Bilate Watershed, Southern Ethiopia. EJAST; 2010 Nov; 1(1): 49-62.

29. Belachew T, Hadley C, Lindstrom D, Gebremariam A, Wolde Michael K, Getachew Y, et.al. Gender Differences in Food Insecurity and Morbidity Among Adolescents in Southwest Ethiopia. American Academy of Pediatrics. Illinois. Jan 10, 2011; DOI: 10.1542/peds.2010-0944.

30. Community-Based Sub-Component of Ethiopian National Nutrition Program. Baseline Survey Report. Addis Continental Institute of Public Health; 2009 Dec; p 1-80.

31. Food Insecurity Persists in Sub-Saharan Africa despite Efforts to Halve Hunger by 2015 . United States Government Accountability Office. Washington, DC. 2008 Jul.

32. Adenegan K, Adewusi O. Determinants of Food Security Status of Rural Households Living With HIV/AIDS in Southwestern Nigeria. African Journal of Biomedical Research. 2007 Vol. 10; 9 - 18.

33. Brown B, Noonan C, Nord M. Prevalence of Food Insecurity and HealthAssociated Outcomes and Food Characteristics of Northern Plains Indian Households. Journal of Hunger \& Environmental Nutrition. 2007; 1(4): 37-53. 
34. Iberg J, Yaro J. An assessment of the extent and causes of food insecurity in Northern Ghana using a livelihood vulnerability framework. GeoJournal; 2006 Oct. 67;41-55.

35. Omotesho O, Adewumi M, Lawal A, Ayinde O. Determinants of Food Security Among The Rural Farming Households in Kwara State, Nigeria. African Journal of General Agriculture; 2006 June; vol. 2. No 1.

36. Impact of USAID/FFP-Funded programs on small holder household food security in Burkina Faso. West African Regional Food for Peace Office; USAID/West African Professional Paper Series; 2009 March; Ser.N0.7.

37. Penh P. Strategic Framework for Food Security and Nutrition in Cambodia 2008-2012. Prepared by the CARD in consultation with TWG-FSN; 2008 May.

38. Food security strategy. Government of the state of Eritrea. Asmara. 2004 Apr.

39. Kidane H, Alemu ZG, Kundhlande G. Causes of Household Food Insecurity in Koredegaga Peasant Association, Oromiya Zone, Ethiopia. Agrekon; 2005; 44: 4, 543-560.

40. Abebaw S. Dimension and determinants of food insecurity among rural households in Dire Dawa, Eastern Ethiopia. MSc thesis presented to the School of Graduate Studies of Alemaya University; 2003; 112-118.

41. Position of the American Dietetic Association: Food Insecurity and Hunger in the United States. Journal of The American Dietetic Association; 2006;106:446-458.

42. El-Sayed A, Hadley C, Tessema F, Tegegn A, Cowan J, Galea S. Household food insecurity and symptoms of neurologic disorder in Ethiopia: An observational analysis; BMC Public Health; Columbia University, New York, NY, USA;2010.

43. Alaimo K, Olson CM, Frongillo EA. Food insufficiency and American schoolaged children's cognitive academic and psycho-social development. Pediatrics 2001; 108:44-53.

44. Ashiabi G. Household food insecurity and children's school engagement. Journal of Children and Poverty; 2005; 11: 1, 3 - 17.

45. Food Security Information for Action: Food Security Concepts and Frameworks. Food Security Analysis. FAO; 2008. 
46. Swindale A, Bilinsky P. Development of a Universally Applicable Household Food Insecurity Measurement Tool: Process, Current Status, and Outstanding Issues: American Society for Nutrition; 2006.

47. Coates J, Swindale A, Bilinsky P. Household Food Insecurity Access Scale (HFIAS) for Measurement of Food Access: Indicator Guide VERSION 3. 2007 Aug. 


\title{
Annexes
}

\author{
Annex I. English Consent form \\ University of Gondar \\ College of Medicine and Health Science \\ School of Public Health
}

Questionnaire for Prevalence of Household Food Insecurity and Associated Factors

\section{Consent Statement}

Hello. My name is and I am part of a research team

of University of Gondar.We are collecting information on the prevalence of food insecurity and associated factors among households in the rural community. We would very much appreciate your participation in this effort.We want to ask you whether you or your household members have experined food insecurity conditions with in the past month. Whatever information you provide will be kept strictly confidential. We will record your name on the questionnaire. However, your name will not be identified in any output of this study. Participation in this study is voluntary and you can choose not to answer any individual question or all of the questions. You may also stop the interview completely at any time without any consequences at all. However, we hope that you will participate in this study since the reults will help the government in household food insecurity control effors.You have full right to withdraw from this study at any time without a need to mention the reason why you wanted to withdraw. We value your input to make this study a successful one. If you have questions about the research please contact Mr.Yirdaw Melese, who is principal investigator of this study in the University of Gondar, at +251 (0)918789922. At this time, do you want to ask me anything about the purpose or content of this interview?

Thank you,

Remarks: Mark an "X" on the appropriate response.

Request accepted and Consent Given

Rejected the request

Interviewee Name

Name of witness

Signature:

Date

Name of field worker

Signature:

Signature:

Date

Date 


\section{Annex II. English Questionnaire}

Please fill-out all the relevant information in the table below for all households surveyed. Information should be obtained from each household (preferably women) 18 years and above.

\begin{tabular}{|c|c|c|c|}
\hline S.NO & Questions & Response & $\begin{array}{l}\text { Skip } \\
\text { patter } \\
\text { n }\end{array}$ \\
\hline \multicolumn{4}{|c|}{ Part I. General information } \\
\hline 101 & Household ID & & \\
\hline 102 & Kebele ID & & \\
\hline \multicolumn{4}{|c|}{ Part II: Demographic and socioeconomic characteristics of respondents } \\
\hline 201 & Sex of household head & $\begin{array}{l}\text { 1.Male } \\
\text { 2.Female }\end{array}$ & \\
\hline 202 & $\begin{array}{l}\text { What is the relationship of the } \\
\text { head of the household with } \\
\text { household members? }\end{array}$ & $\begin{array}{l}\text { 1.Father } \\
\text { 2.Mother } \\
\text { 3.Son/Daughter } \\
\text { 4.Aunt/Uncle } \\
\text { 5.Grandparent } \\
\text { 6.Other relative } \\
\text { 7.Non-relative } \\
\text { 8.Other (specify) }\end{array}$ & \\
\hline 203 & Age of household head in year & & \\
\hline 204 & Family size & & \\
\hline 205 & Ethnicity & $\begin{array}{ll}\text { 1.Amhara } & \text { 2.Oromo } \\
\text { 3.Tigre } & \text { 4.Other }\end{array}$ & \\
\hline 206 & Religion & $\begin{array}{ll}\text { 1.Orthodox } & \text { 2.Islam } \\
\text { 3.Protestant } & \text { 4.Catholic } \\
\text { 5.Others } & \end{array}$ & \\
\hline
\end{tabular}




\begin{tabular}{|c|c|c|}
\hline 207 & Education & $\begin{array}{l}\text { 1.Illiterate } \quad \text { 2.Read and write } \\
\text { 3.Primary } \quad \text { 4.Secondary } \\
\text { 5.Post-secondary }\end{array}$ \\
\hline 208 & Marital status & $\begin{array}{ll}\text { 1.Single } & \text { 2.Married } \\
\text { 3.Divorced } & \text { 4.Widowed }\end{array}$ \\
\hline 209 & Occupation & $\begin{array}{l}\text { 1.Peasant } \\
\text { 2.Student } \\
\text { 3.Petty trade } \\
\text { 4.Civil servant } \\
\text { 5.Private business } \\
\text { 6.Unemployed } \\
\text { 7.Other (specify) }\end{array}$ \\
\hline 210 & $\begin{array}{l}\text { Does the household have } \\
\text { Farm land? }\end{array}$ & $\begin{array}{l}\text { 1.Yes } \\
\text { 2.No }\end{array}$ \\
\hline 211 & $\begin{array}{l}\text { What is the household's farm } \\
\text { size in "kada" ( } 1 \text { ha }=10,000 \mathrm{~m}^{2} \\
=4 \text { "kada" or "Timad")? }\end{array}$ & \\
\hline 212 & $\begin{array}{l}\text { Does the household have } \\
\text { access to irrigation? }\end{array}$ & $\begin{array}{l}\text { 1.Yes } \\
2 . \text { No }\end{array}$ \\
\hline 213 & $\begin{array}{l}\text { Does the household use } \\
\text { fertilizers? }\end{array}$ & $\begin{array}{l}\text { 1.Yes } \\
\text { 2.No }\end{array}$ \\
\hline 214 & $\begin{array}{l}\text { If your answer is yes for Q212 } \\
\text { what type of fertilizer did your } \\
\text { household used? }\end{array}$ & $\begin{array}{l}\text { 1.Artificial } \\
\text { 2.Compost (Natural) } \\
\text { 3.Both }\end{array}$ \\
\hline 215 & $\begin{array}{l}\text { Does the household have } \\
\text { income from vegetables and } \\
\text { or fruits? }\end{array}$ & $\begin{array}{l}\text { 1.Yes } \\
2 . \text { No }\end{array}$ \\
\hline 216 & $\begin{array}{l}\text { For what purpose do the } \\
\text { household use vegetables? }\end{array}$ & $\begin{array}{l}\text { 1. Totally for sell } \\
\text { 2.Partially for sell } \\
\text { 3. Totally for household } \\
\text { consumption }\end{array}$ \\
\hline
\end{tabular}




\begin{tabular}{|c|c|c|}
\hline 217 & $\begin{array}{l}\text { If your answer is } 1 \text { or } 2 \text { for } \\
\text { Q215, what is the average } \\
\text { annual income earned from } \\
\text { vegetables, fruits and or } \\
\text { perennial crops? }\end{array}$ & \\
\hline 218 & $\begin{array}{l}\text { What is this year's household } \\
\text { average annual crop } \\
\text { production? }\end{array}$ & $\begin{array}{l}\text { In "chan" } \\
\text { In "Madiga" }\end{array}$ \\
\hline 219 & $\begin{array}{l}\text { Do you have the following } \\
\text { among the household } \\
\text { members? } \\
\text { 219.1.bicycle } \\
\text { 219.2.motor bicycle } \\
\text { 219.3.radio } \\
\text { 219.4.television } \\
\text { 219.5.car }\end{array}$ & $\begin{array}{lll} & & \begin{array}{l}\text { If the answer is } \\
\text { yes how many? }\end{array} \\
\text { 1. Yes } & \text { 2.No } & \\
\text { 1. Yes } & 2 . \text { No } & \\
\text { 1. Yes } & \text { 2.No } & \\
\text { 1. Yes } & \text { 2.No } & \\
\text { 1. Yes } & \text { 2.No } & \\
\end{array}$ \\
\hline 220 & $\begin{array}{l}\text { Does the household own } \\
\text { livestock? } \\
\text { 220.1.cattle } \\
\text { 220.2.equines } \\
\text { 220.3.goat/sheep } \\
\text { 220.4.poultry }\end{array}$ & $\begin{array}{l}\text { 1. Yes } \\
\text { 2. No } \\
\text { If the answer is yes how many? }\end{array}$ \\
\hline 221 & $\begin{array}{l}\text { Do animals live in the same } \\
\text { house where the members of } \\
\text { the family live? }\end{array}$ & $\begin{array}{l}\text { 1.Yes } \\
2 . \text { No }\end{array}$ \\
\hline 222 & $\begin{array}{l}\text { Does the household have } \\
\text { off-farm income? }\end{array}$ & $\begin{array}{l}\text { 1.Yes } \\
\text { 2.No }\end{array}$ \\
\hline 223 & $\begin{array}{l}\text { If your answer for Qn. } 222 \text { is } \\
\text { yes, what is the average } \\
\text { monthly income in birr? }\end{array}$ & \\
\hline
\end{tabular}




\begin{tabular}{|c|c|c|}
\hline 224 & $\begin{array}{l}\text { What is the total average } \\
\text { annual farm income for the } \\
\mathrm{Hh} \text { ? }\end{array}$ & \\
\hline 225 & $\begin{array}{l}\text { What is the total average } \\
\text { household's monthly income in } \\
\text { birr? }\end{array}$ & \\
\hline \multicolumn{3}{|c|}{ Part III. Water and sanitary conditions } \\
\hline 301 & $\begin{array}{l}\text { From where do you get water } \\
\text { for drinking? }\end{array}$ & $\begin{array}{l}\text { 1. Pipe } \\
\text { 2. Protected spring } \\
\text { 3. Protected well } \\
\text { 4. Unprotected spring } \\
\text { 5.Unprotected well } \\
\text { 6. River } \\
\text { 5. Other (specify) }\end{array}$ \\
\hline 302 & $\begin{array}{l}\text { What type of collection } \\
\text { container the household use? }\end{array}$ & $\begin{array}{l}\text { 1. Jerry can } \\
\text { 2.Iron bucket } \\
\text { 3. Pot } \\
\text { 4. Other (specify) }\end{array}$ \\
\hline 303 & $\begin{array}{l}\text { How many minutes/hours do } \\
\text { you take to fetch water }\end{array}$ & $\begin{array}{l}\text { 1. } 1-15 \text { minutes } \\
\text { 2. } 16-30 \text { minutes } \\
\text { 3. } 31-60 \text { minutes } \\
\text { 4. More than } 1 \text { hour }\end{array}$ \\
\hline 304 & Is latrine available? & $\begin{array}{l}\text { 1.Yes } \\
2 . \text { No }\end{array}$ \\
\hline 305 & $\begin{array}{l}\text { If the answer for Qn. } 29 \text { is yes, } \\
\text { what type of latrine is it? }\end{array}$ & $\begin{array}{l}\text { 1.latrine with water } \\
\text { 2.pit latrine with shelter } \\
\text { 3.pit latrine without shelter } \\
\text { 4.latrine with no smell } \\
\text { 5.Other (specify) }\end{array}$ \\
\hline 306 & $\begin{array}{l}\text { Do members of the household } \\
\text { wash their hand after toilet }\end{array}$ & $\begin{array}{l}\text { 1.Yes always 2.Yes sometimes } \\
\text { 3.No }\end{array}$ \\
\hline
\end{tabular}




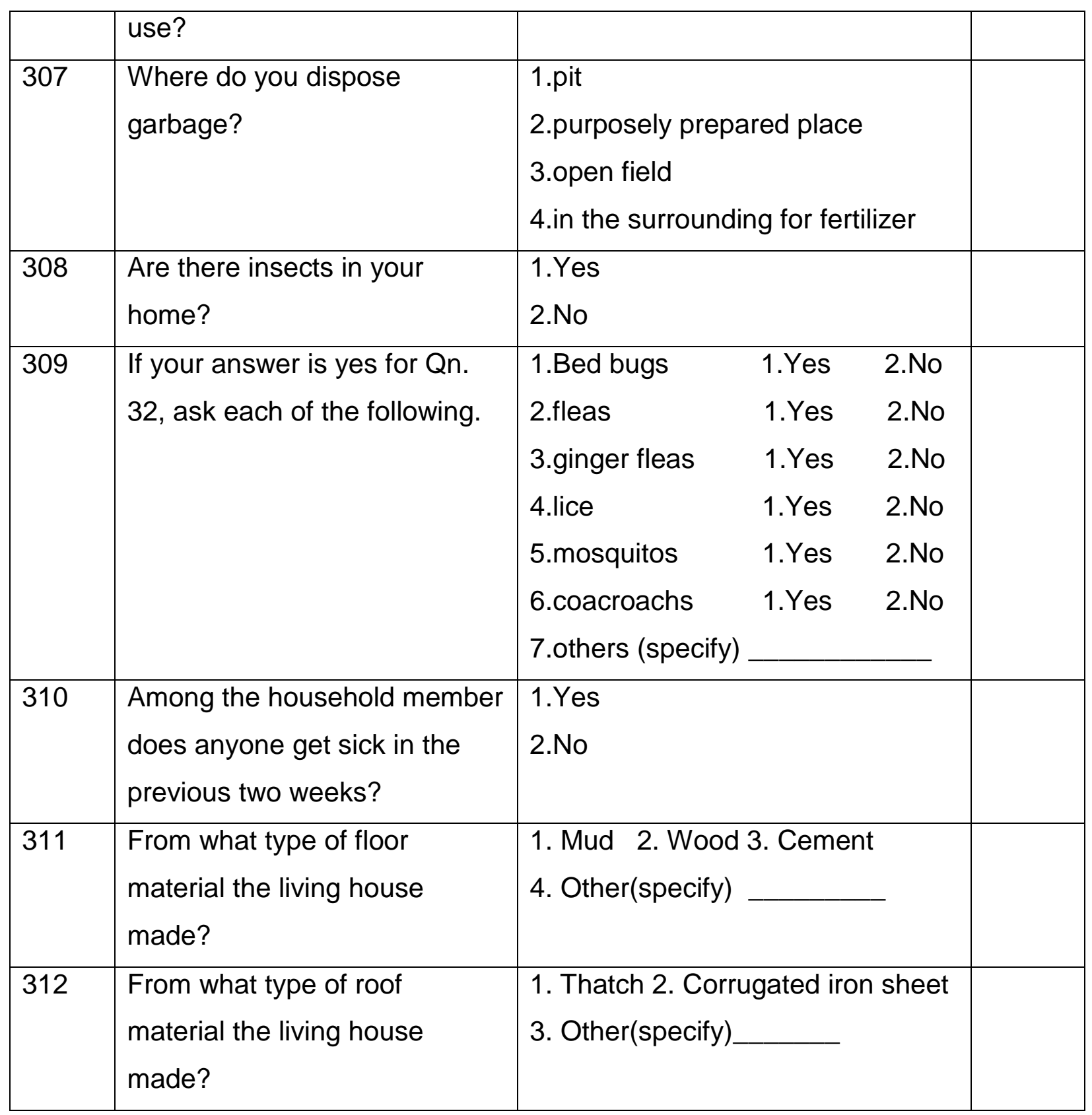




\begin{tabular}{|c|c|c|c|}
\hline \multicolumn{4}{|c|}{ Part III. Household Food Insecurity Access Scale (HFIAS) Measurement Tool } \\
\hline 401 & $\begin{array}{l}\text { In the past four weeks, did } \\
\text { you worry that your } \\
\text { household would not have } \\
\text { enough food? }\end{array}$ & $\begin{array}{l}0=\text { No (skip to Q2) } \\
1=\text { Yes }\end{array}$ & \\
\hline $401 a$ & How often did this happen? & $\begin{array}{l}1 \text { = Rarely (once or twice in } \\
\text { the past four weeks) } \\
2 \text { = Sometimes (three to ten } \\
\text { times in the past four weeks) } \\
3=\text { Often (more than ten times } \\
\text { in the past four weeks) }\end{array}$ & \\
\hline 402 & $\begin{array}{l}\text { In the past four weeks, were } \\
\text { you or any household } \\
\text { member not able to eat the } \\
\text { kinds of foods you preferred } \\
\text { because of a lack of } \\
\text { resources? }\end{array}$ & $\begin{array}{l}0=\text { No (skip to Q3) } \\
1=\text { Yes }\end{array}$ & \\
\hline $402 a$ & How often did this happen? & $\begin{array}{l}1 \text { = Rarely (once or twice in } \\
\text { the past four weeks) } \\
2 \text { = Sometimes (three to ten } \\
\text { times in the past four weeks) } \\
3 \text { = Often (more than ten times } \\
\text { in the past four weeks) }\end{array}$ & \\
\hline 403 & $\begin{array}{l}\text { In the past four weeks, did } \\
\text { you or any household } \\
\text { member have to eat a } \\
\text { limited variety of foods due } \\
\text { to a lack of resources? }\end{array}$ & $\begin{array}{l}0=\text { No (skip to Q4) } \\
1=\text { Yes }\end{array}$ & \\
\hline $403 a$ & How often did this happen? & $\begin{array}{l}1 \text { = Rarely (once or twice in } \\
\text { the past four weeks) } \\
2 \text { = Sometimes (three to ten }\end{array}$ & \\
\hline
\end{tabular}




\begin{tabular}{|c|c|c|}
\hline & & $\begin{array}{l}\text { times in the past four weeks) } \\
3=\text { Often (more than ten times } \\
\text { in the past four weeks) }\end{array}$ \\
\hline 404 & $\begin{array}{l}\text { In the past four weeks, did } \\
\text { you or any household } \\
\text { member have to eat some } \\
\text { foods that you really did not } \\
\text { want to eat because of a } \\
\text { lack of resources to obtain } \\
\text { other types of food? }\end{array}$ & $\begin{array}{l}0=\text { No }(\text { skip to Q5) } \\
1=\text { Yes }\end{array}$ \\
\hline $404 a$ & How often did this happen? & $\begin{array}{l}1 \text { = Rarely (once or twice in } \\
\text { the past four weeks) } \\
2 \text { = Sometimes (three to ten } \\
\text { times in the past four weeks) } \\
3=\text { Often (more than ten times } \\
\text { in the past four weeks) }\end{array}$ \\
\hline 405 & $\begin{array}{l}\text { In the past four weeks, did } \\
\text { you or any household } \\
\text { member have to eat a } \\
\text { smaller meal than you felt } \\
\text { you needed because there } \\
\text { was not enough food? }\end{array}$ & $\begin{array}{l}0=\text { No (skip to Q6) } \\
1=\text { Yes }\end{array}$ \\
\hline $405 a$ & How often did this happen? & $\begin{array}{l}1 \text { = Rarely (once or twice in } \\
\text { the past four weeks) } \\
2 \text { = Sometimes (three to ten } \\
\text { times in the past four weeks) } \\
3=\text { Often (more than ten times } \\
\text { in the past four weeks) }\end{array}$ \\
\hline 406 & $\begin{array}{l}\text { In the past four weeks, did } \\
\text { you or any other household } \\
\text { member have to eat fewer }\end{array}$ & $\begin{array}{l}0=\text { No (skip to Q7) } \\
1=\text { Yes }\end{array}$ \\
\hline
\end{tabular}




\begin{tabular}{|c|c|c|}
\hline & $\begin{array}{l}\text { meals in a day because } \\
\text { there was not enough food? }\end{array}$ & \\
\hline $406 a$ & How often did this happen? & $\begin{array}{l}1 \text { = Rarely (once or twice in } \\
\text { the past four weeks) } \\
2 \text { = Sometimes (three to ten } \\
\text { times in the past four weeks) } \\
3=\text { Often (more than ten times } \\
\text { in the past four weeks) }\end{array}$ \\
\hline 407 & $\begin{array}{l}\text { In the past four weeks, was } \\
\text { there ever no food to eat of } \\
\text { any kind in your household } \\
\text { because of lack of } \\
\text { resources to get food? }\end{array}$ & $\begin{array}{l}0=\text { No }(\text { skip to Q8) } \\
1=\text { Yes }\end{array}$ \\
\hline $407 a$ & How often did this happen? & $\begin{array}{l}1 \text { = Rarely (once or twice in } \\
\text { the past four weeks) } \\
2 \text { = Sometimes (three to ten } \\
\text { times in the past four weeks) } \\
3=\text { Often (more than ten times } \\
\text { in the past four weeks) }\end{array}$ \\
\hline 408 & $\begin{array}{l}\text { In the past four weeks, did } \\
\text { you or any household } \\
\text { member go to sleep at } \\
\text { night hungry because there } \\
\text { was not enough food? }\end{array}$ & $\begin{array}{l}0=\text { No (skip to Q9) } \\
1=\text { Yes }\end{array}$ \\
\hline $408 a$ & How often did this happen? & $\begin{array}{l}1 \text { = Rarely (once or twice in } \\
\text { the past four weeks) } \\
2 \text { = Sometimes (three to ten } \\
\text { times in the past four weeks) } \\
3=\text { Often (more than ten times } \\
\text { in the past four weeks) }\end{array}$ \\
\hline 409 & In the past four weeks, did & $0=$ No (questionnaire is \\
\hline
\end{tabular}




\begin{tabular}{|l|l|l|l|}
\hline & $\begin{array}{l}\text { you or any household } \\
\text { member go a whole day and } \\
\text { night without eating anything } \\
\text { because there was not } \\
\text { enough food? }\end{array}$ & $\begin{array}{l}\text { finished) } \\
1=\text { Yes }\end{array}$ & \\
\hline $409 \mathrm{a}$ & How often did this happen? & $\begin{array}{l}1 \text { = Rarely (once or twice in } \\
\text { the past four weeks) } \\
2=\text { Sometimes (three to ten } \\
\text { times in the past four weeks) } \\
3=\text { Often (more than ten times } \\
\text { in the past four weeks) }\end{array}$ & \\
\hline
\end{tabular}

Thank you 


\title{
Annex III. Amharic Consent Form
}

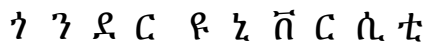

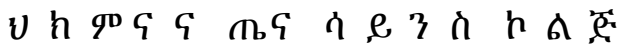

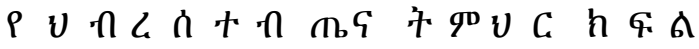

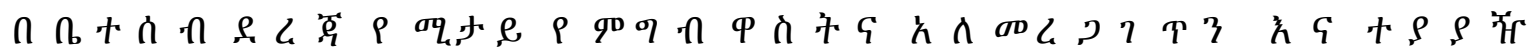

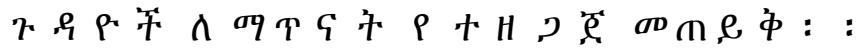

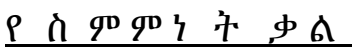

nद i $0 \cdot:: \cap ; 3, P C$

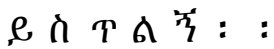

तो ${ }^{o g}$

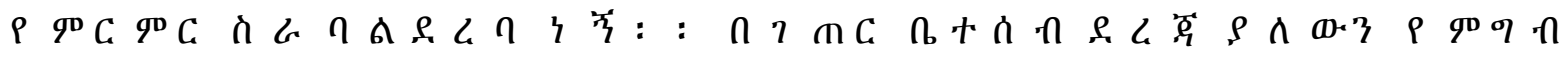

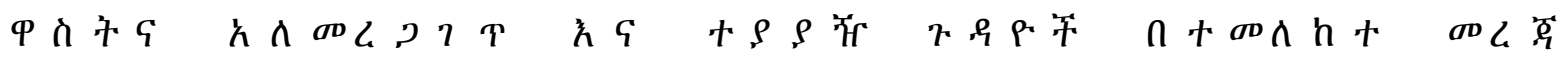

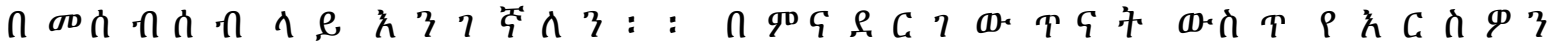

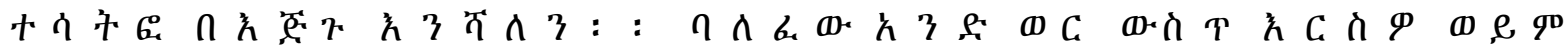

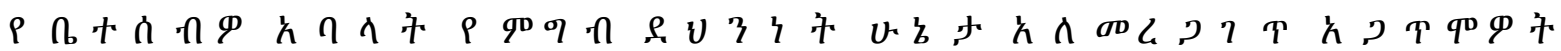

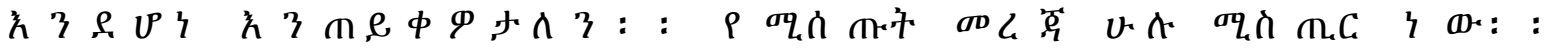
तो qD $\rho$ वq.aD

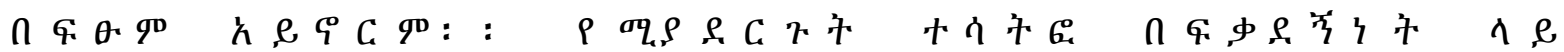

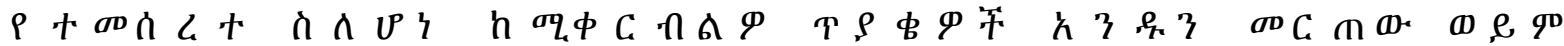

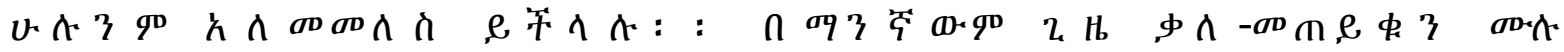

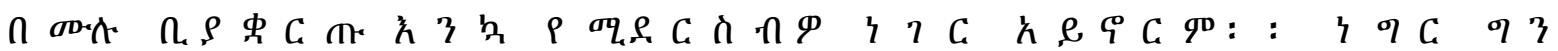
P H.

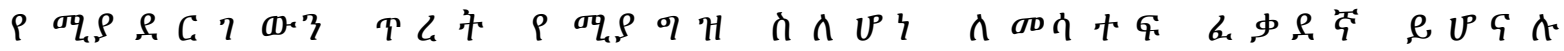

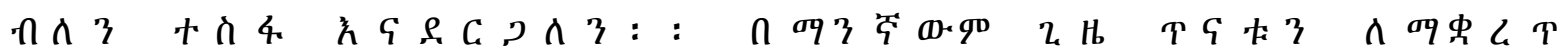

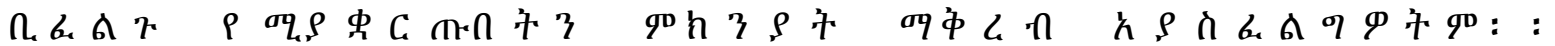

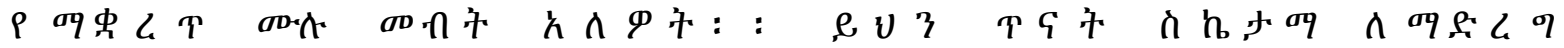

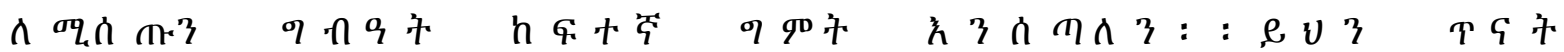

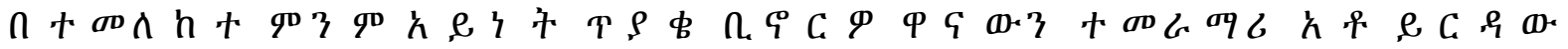

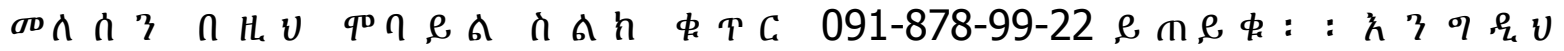

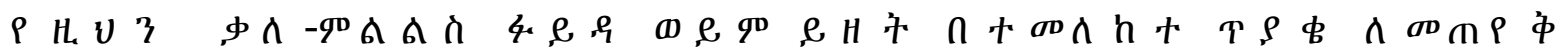

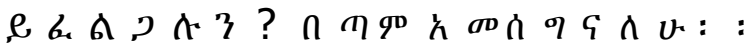

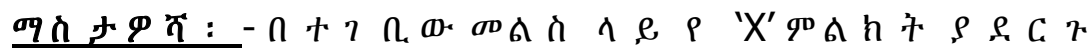

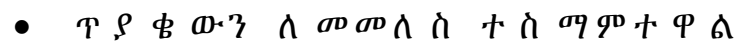

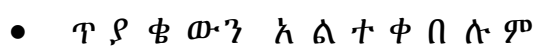

- $\quad p+\pi \rho$ q a d d 6. C. oq 中 3

- $\quad p$ gda ha di b. $C$ ar \$3 


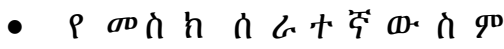
6. $C$ oq \$3

- \$

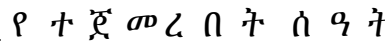

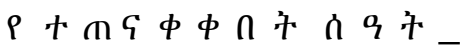

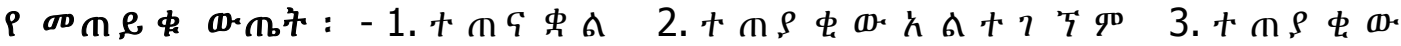

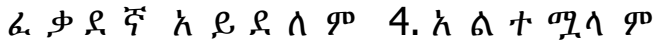

$\rho<, 7 \pi \omega^{*}+\$ \pi \pi b$ तो $q^{\mathrm{D}}$ 6. C. 97 \$ 3

\section{Annex IV. Amharic Questionnaire}

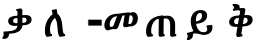

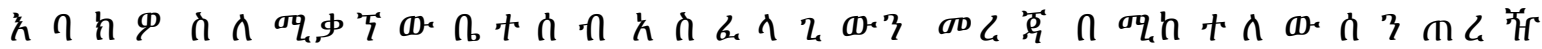

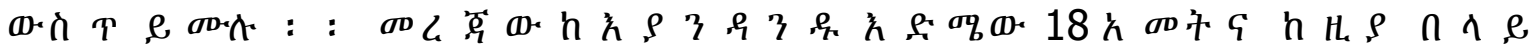

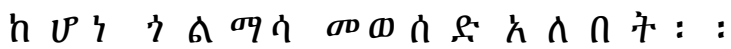

\begin{tabular}{|c|c|c|c|}
\hline.$+ \phi$ & 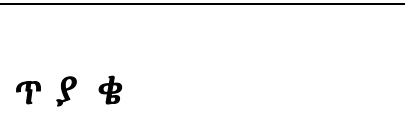 & $\operatorname{\theta os} \lambda \hat{\lambda}$ & od \\
\hline \multicolumn{4}{|c|}{ 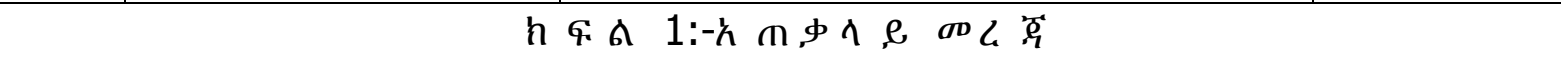 } \\
\hline 101 & 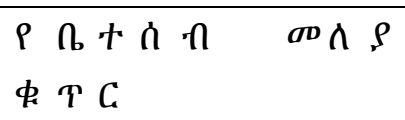 & & \\
\hline 102 & $\begin{array}{l}\rho \phi \cap \Lambda \quad \sigma D \Lambda \rho \\
\phi T C\end{array}$ & & \\
\hline \multicolumn{4}{|c|}{ Һ } \\
\hline 201 & 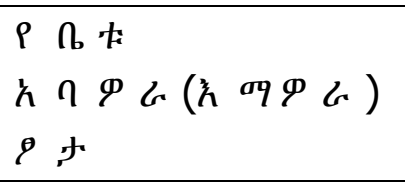 & $\begin{array}{l}1.039 \\
2 . \dot{6} \text { 市 }\end{array}$ & \\
\hline 202 & 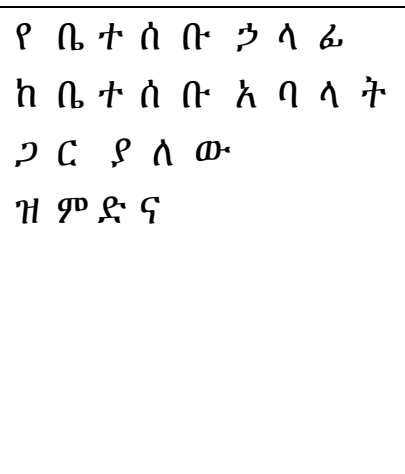 & 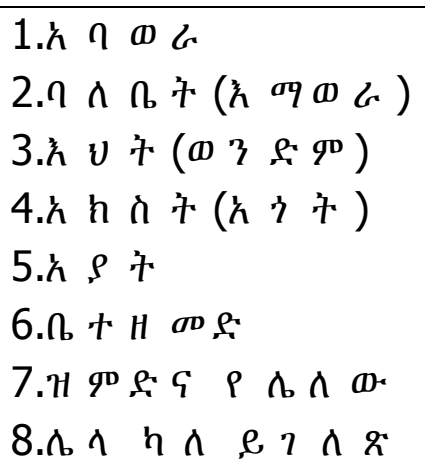 & \\
\hline 203 & 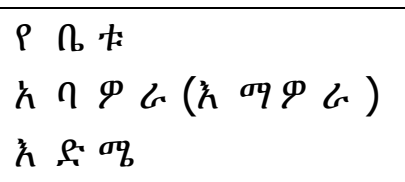 & & \\
\hline 204 & 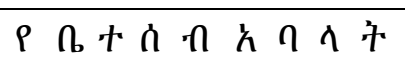 & & \\
\hline
\end{tabular}




\begin{tabular}{|c|c|c|c|}
\hline & 几 म & & \\
\hline 205 & $\cap \pitchfork C$ & 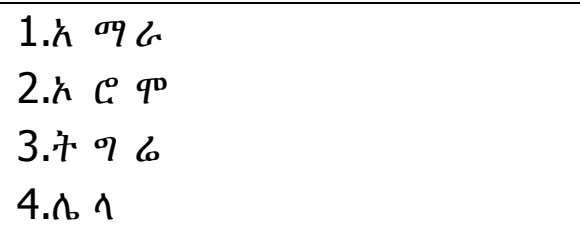 & \\
\hline 206 & $v, e$ 叫市 & 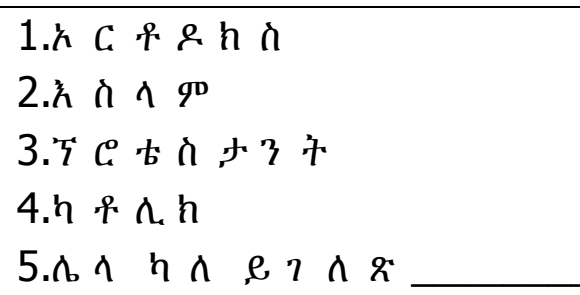 & \\
\hline 207 & 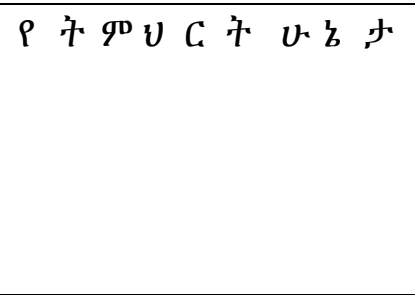 & 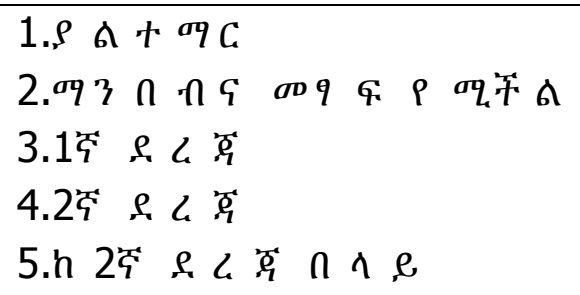 & \\
\hline 208 & 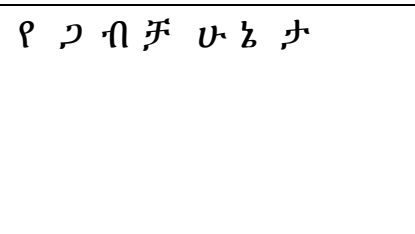 & 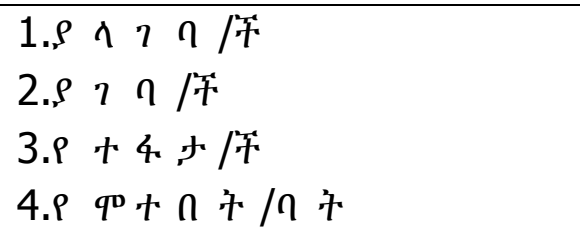 & \\
\hline 209 & 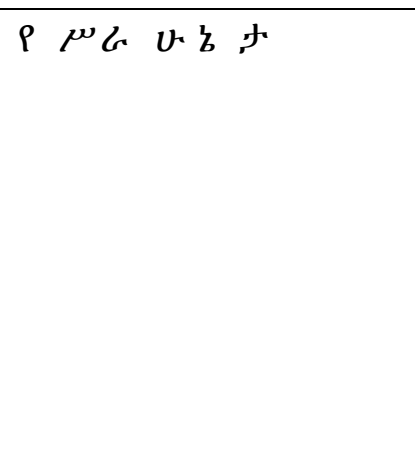 & 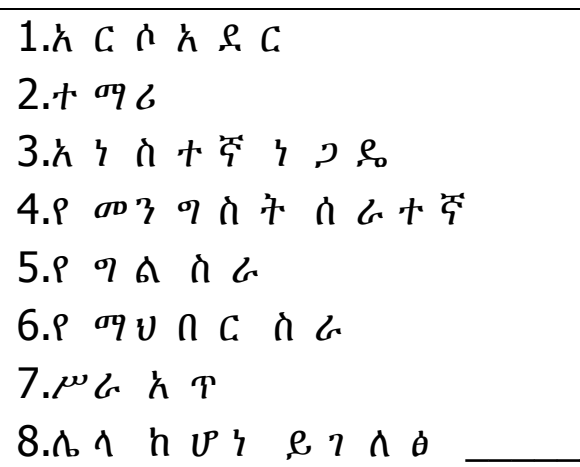 & \\
\hline 210 & 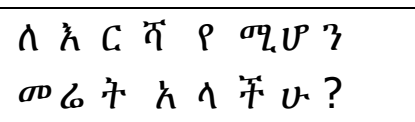 & $\begin{array}{l}1 . h \quad 9 \quad 3 \\
2.9 \times 90\end{array}$ & \\
\hline 211 & 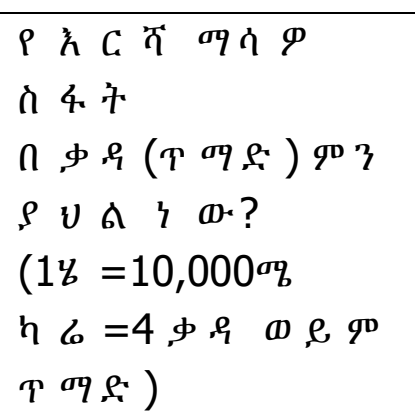 & & \\
\hline 212 & 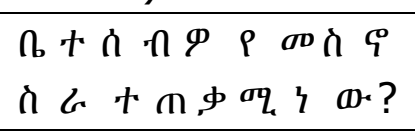 & 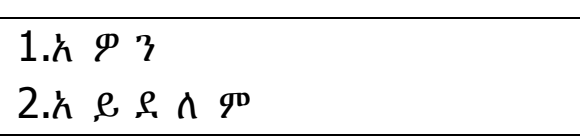 & \\
\hline
\end{tabular}




\begin{tabular}{|c|c|c|}
\hline 213 & 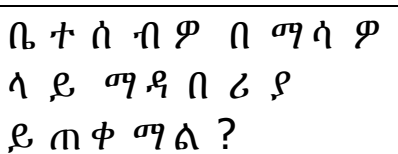 & 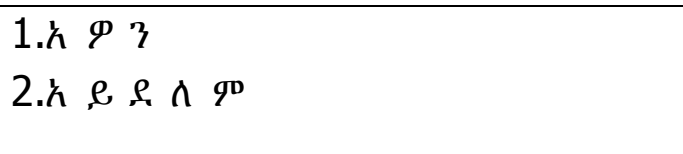 \\
\hline 214 & 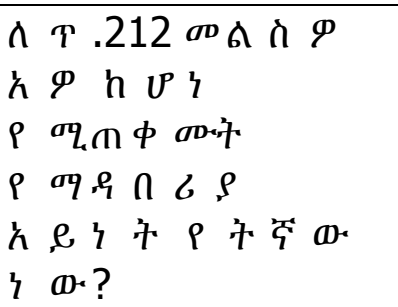 & 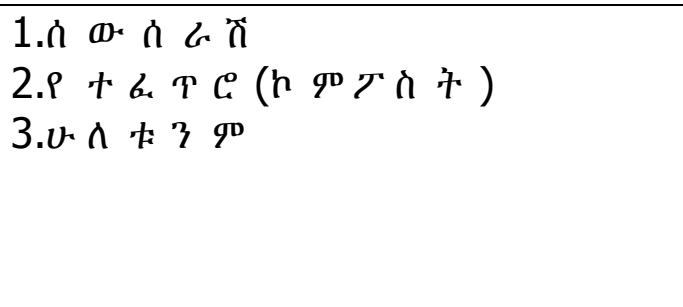 \\
\hline 215 & 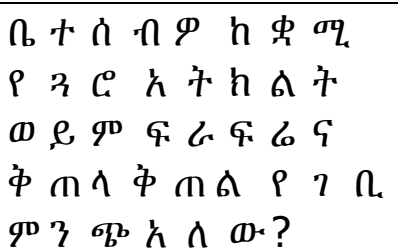 & $\begin{array}{l}\text { 1. ' } \Phi \\
\text { 2. } \rho \wedge a \cdot q \mathrm{~d}\end{array}$ \\
\hline 216 & 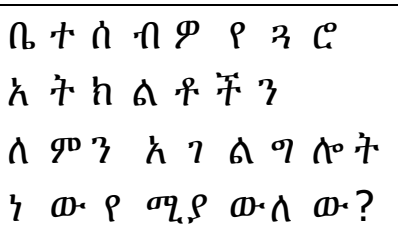 & 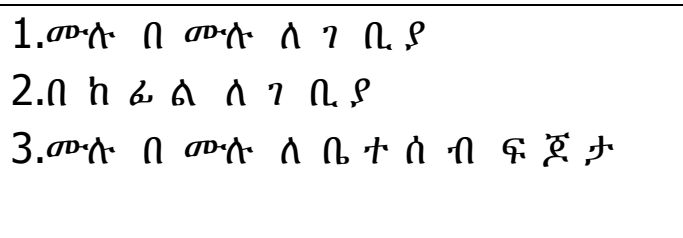 \\
\hline 217 & 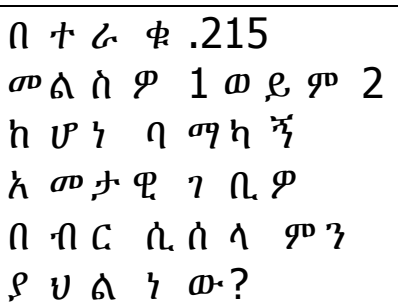 & \\
\hline 218 & 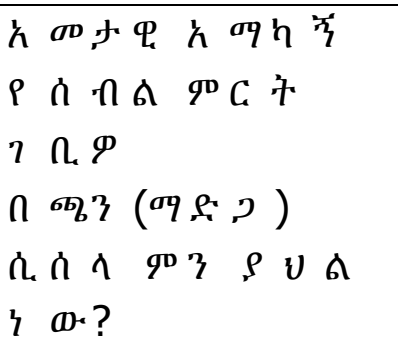 & 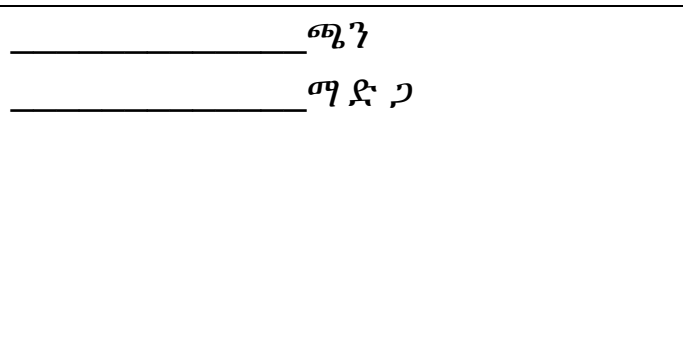 \\
\hline 219 & 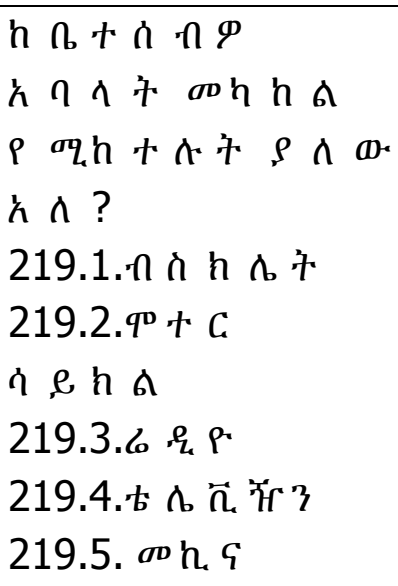 & 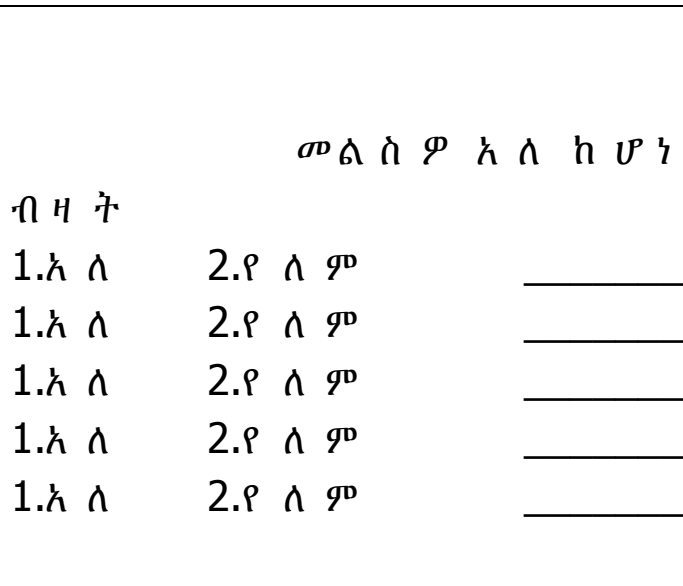 \\
\hline
\end{tabular}




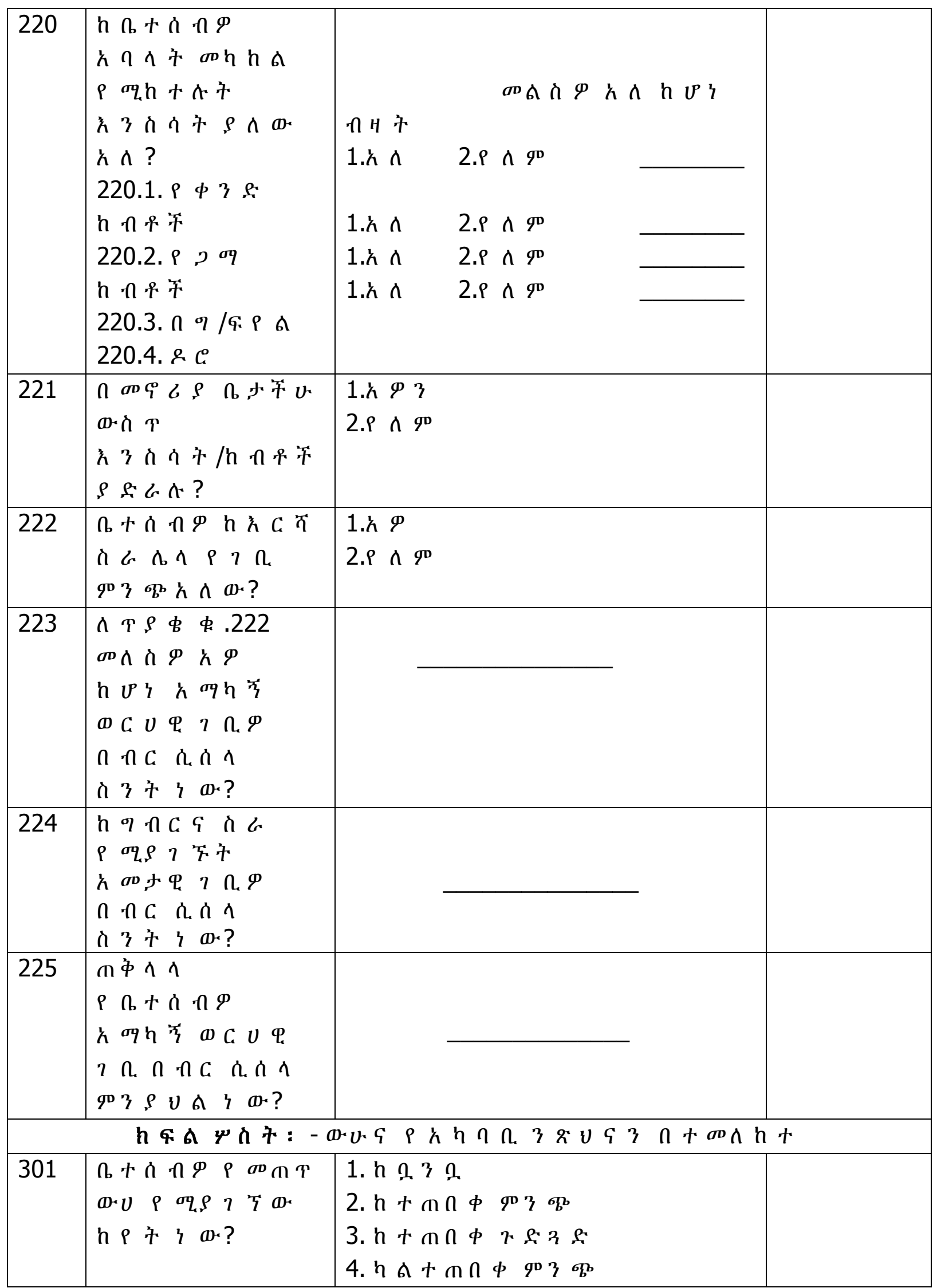




\begin{tabular}{|c|c|c|}
\hline & & 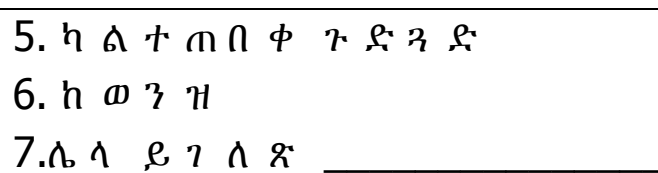 \\
\hline 302 & 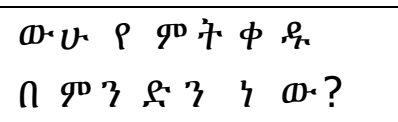 & 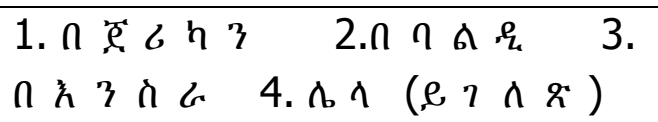 \\
\hline 303 & 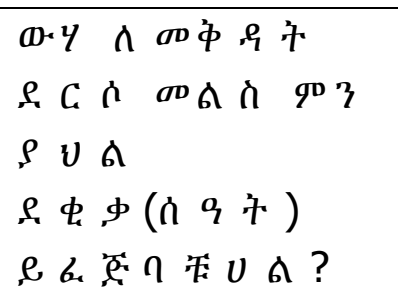 & 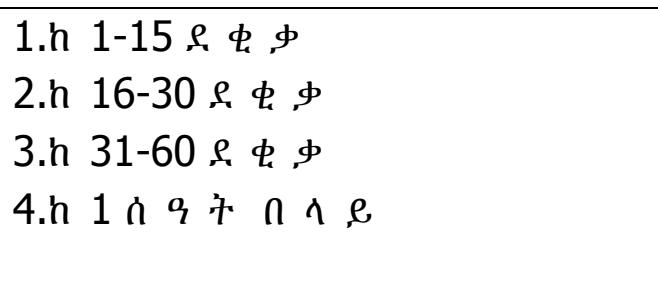 \\
\hline 304 & 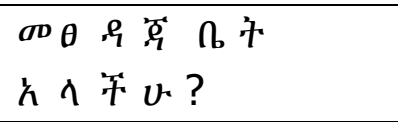 & 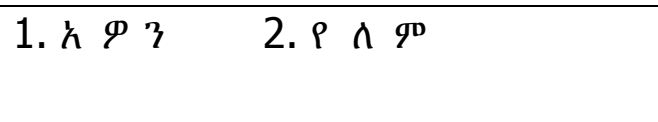 \\
\hline 305 & 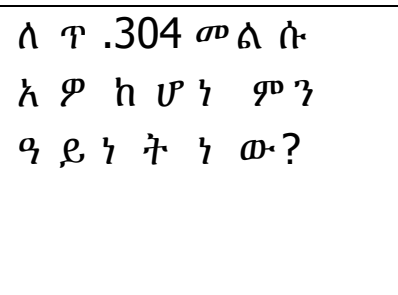 & 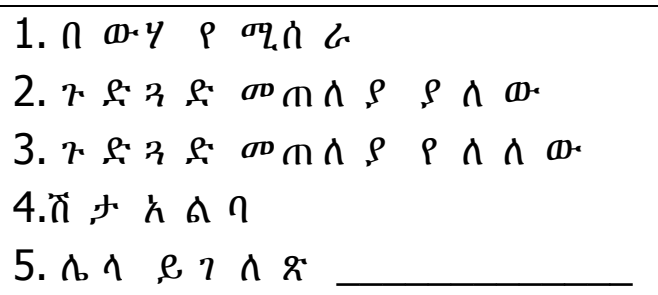 \\
\hline 306 & 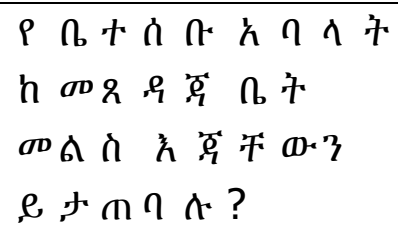 & 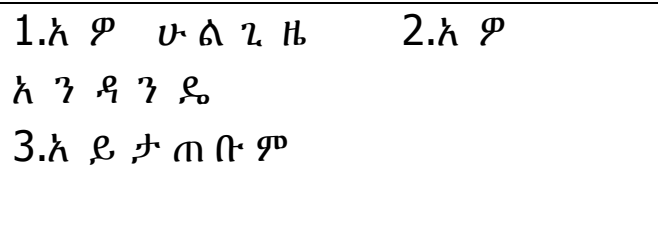 \\
\hline 307 & 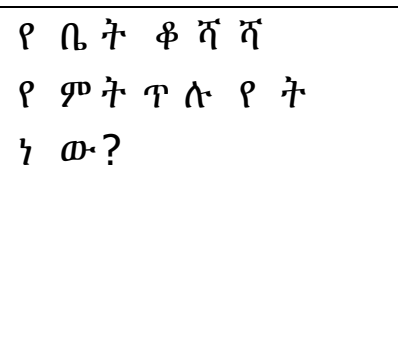 & 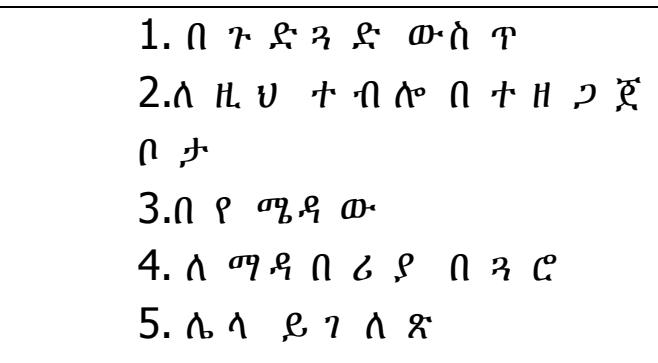 \\
\hline 308 & 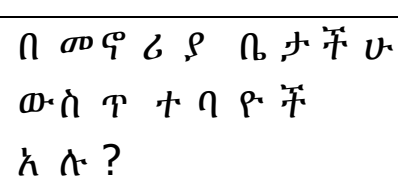 & $\begin{array}{l}\text { 1. h } 97 \\
\text { 2. } \rho \wedge q D\end{array}$ \\
\hline 309 & 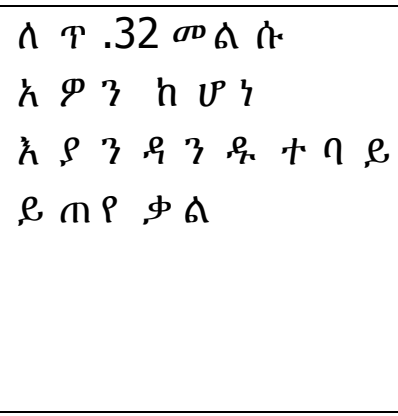 & 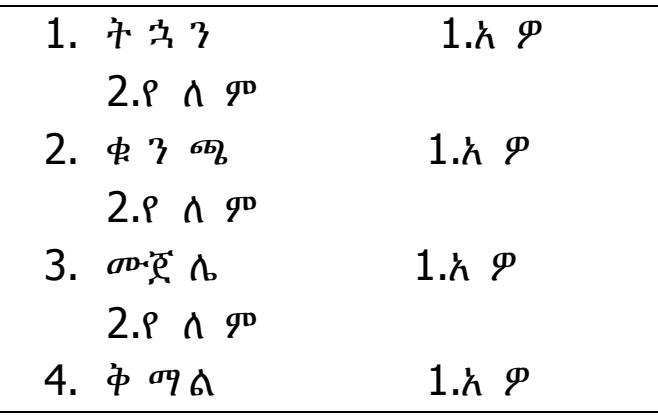 \\
\hline
\end{tabular}




\begin{tabular}{|c|c|c|c|}
\hline & 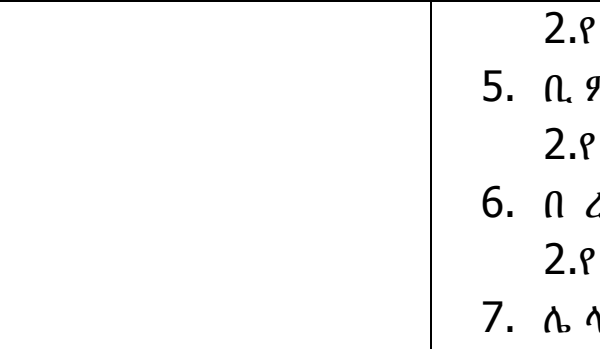 & 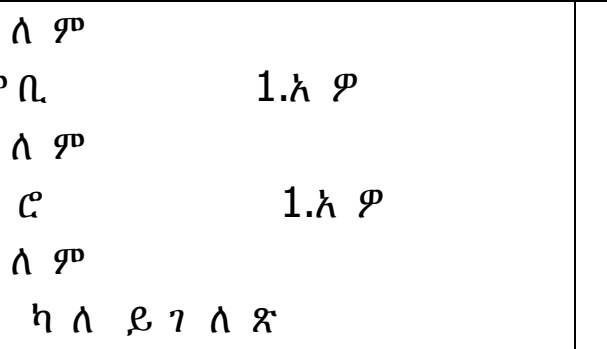 & \\
\hline 310 & 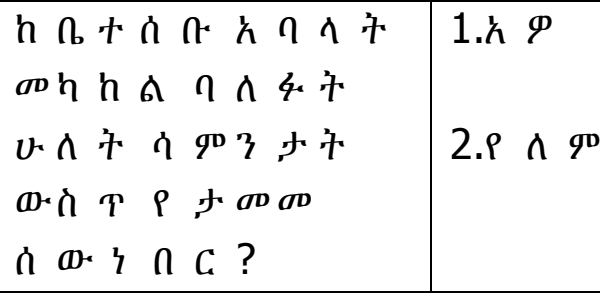 & 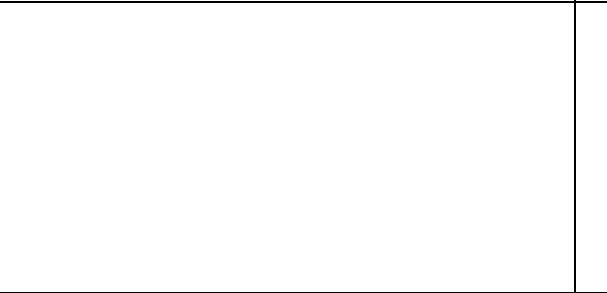 & \\
\hline 311 & 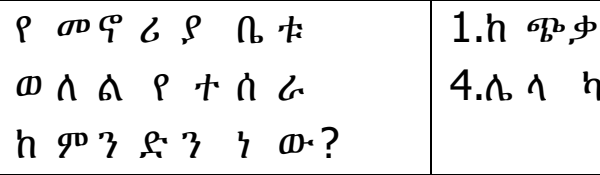 & 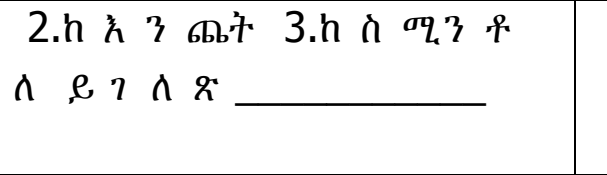 & \\
\hline 312 & 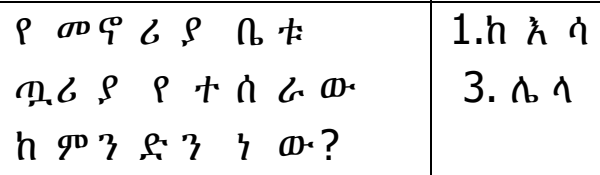 & 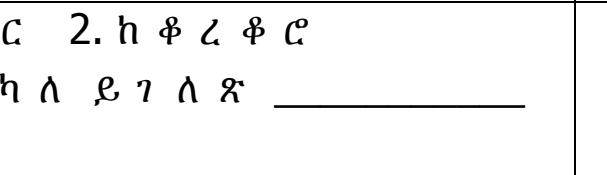 & \\
\hline \multicolumn{4}{|c|}{ Һ } \\
\hline 401 & 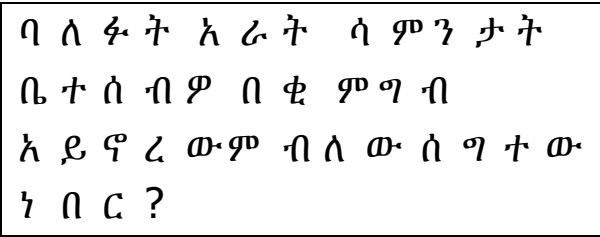 & 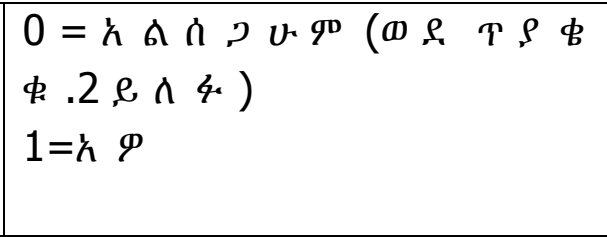 & \\
\hline $401 a$ & 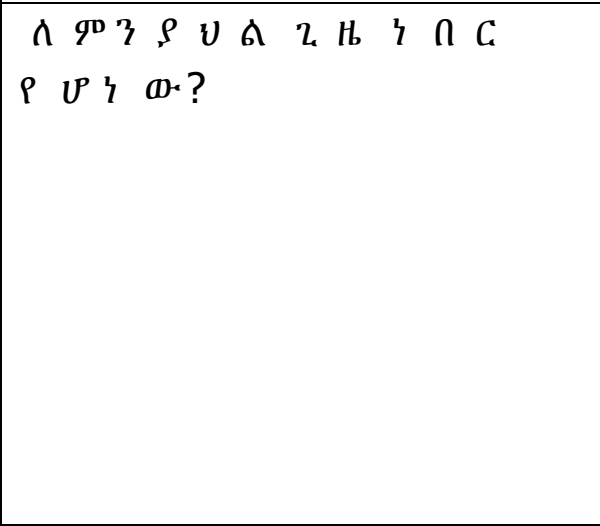 & 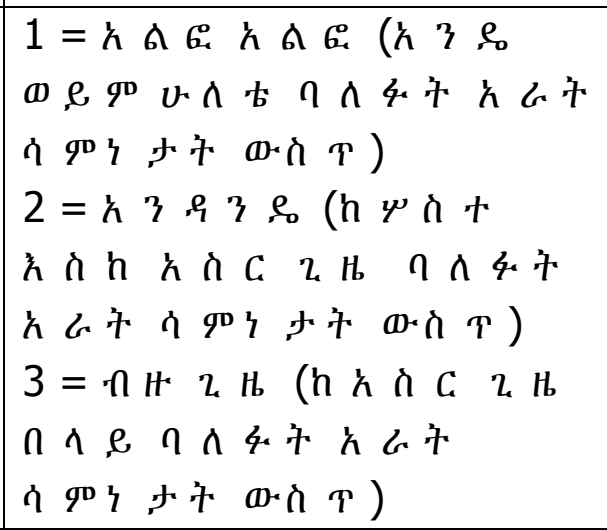 & \\
\hline 402 & 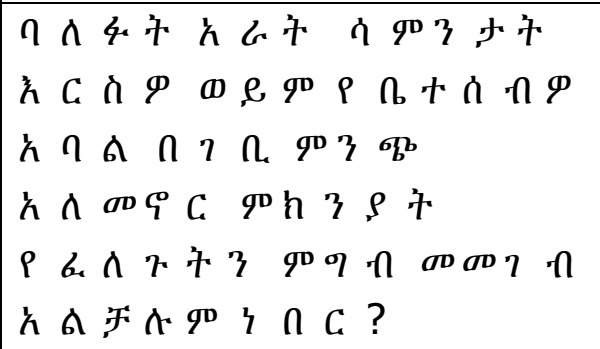 & 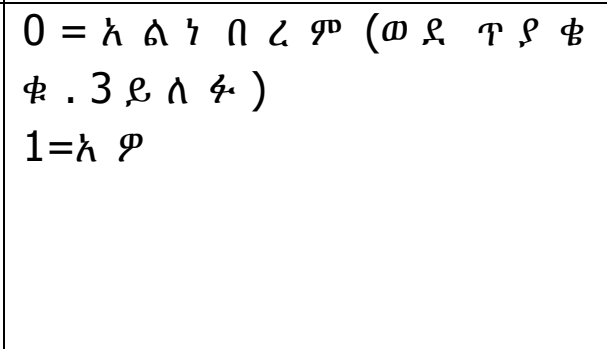 & \\
\hline $402 a$ & 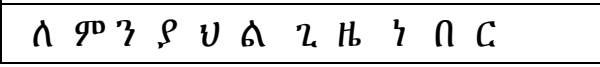 & 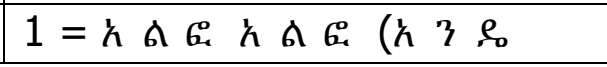 & \\
\hline
\end{tabular}




\begin{tabular}{|c|c|c|}
\hline & $\left.P U^{\prime}\right\} a \cdot ?$ & 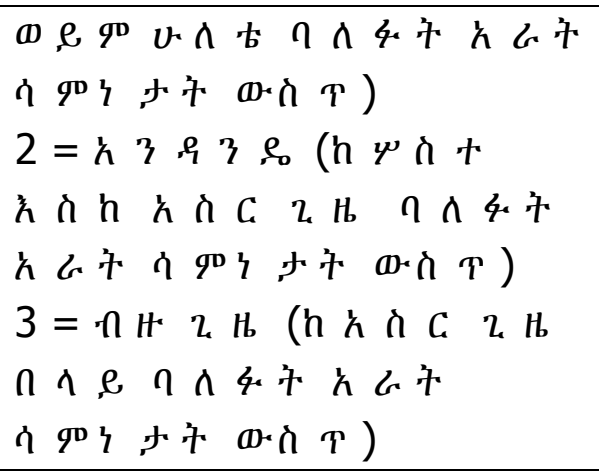 \\
\hline 403 & 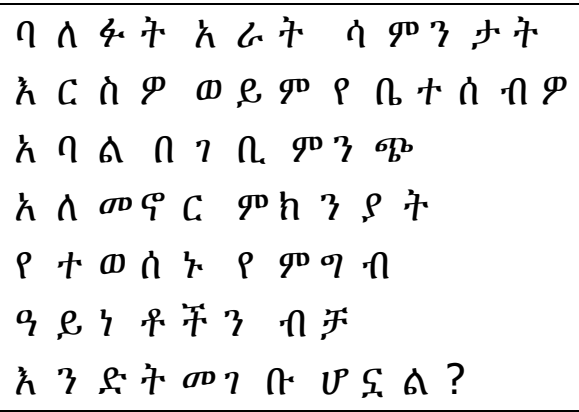 & 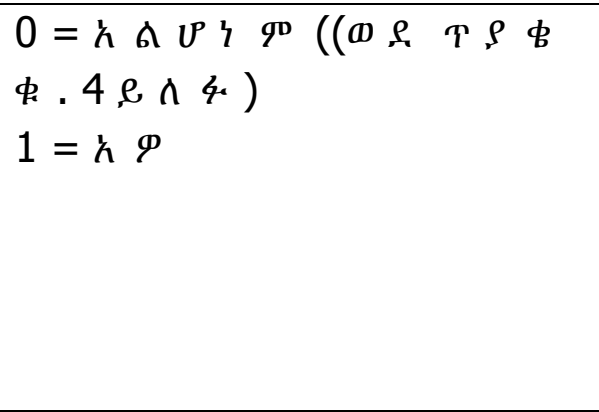 \\
\hline $403 a$ & 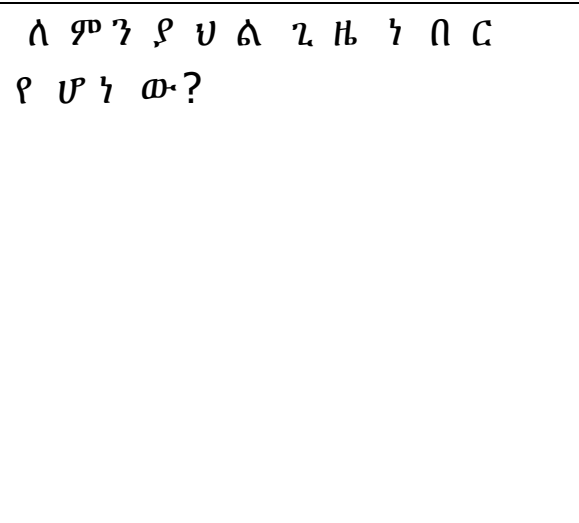 & 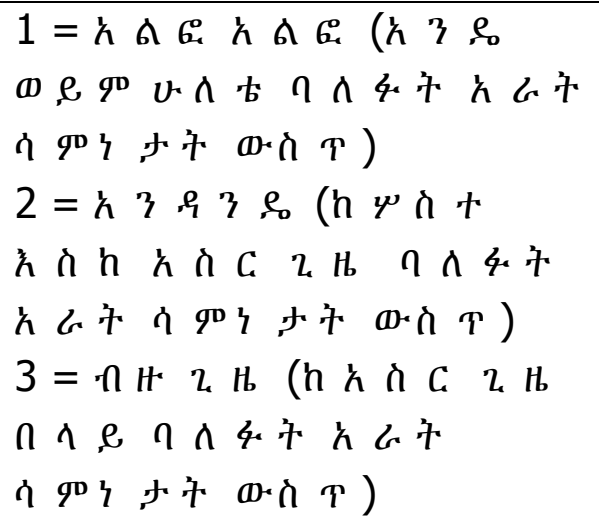 \\
\hline 404 & 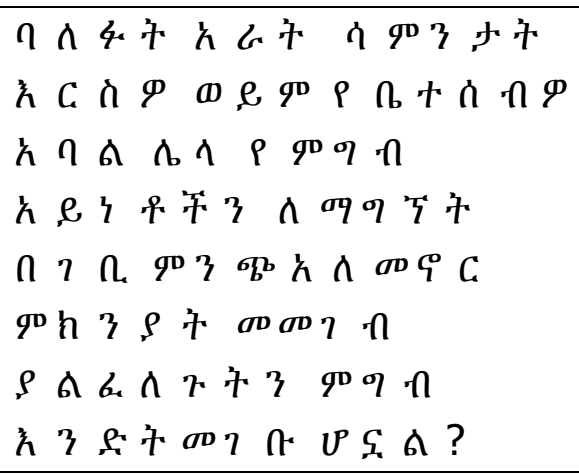 & 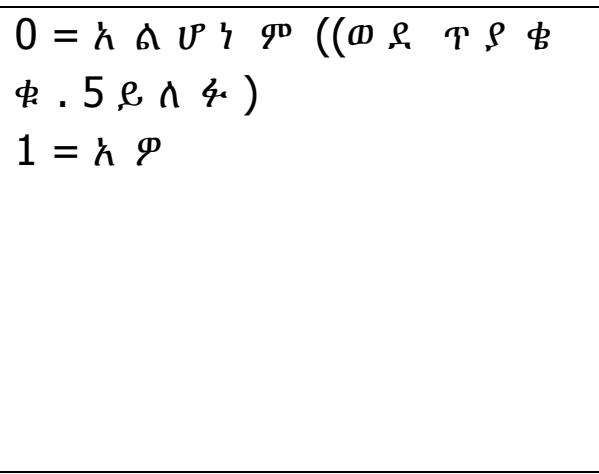 \\
\hline $404 a$ & 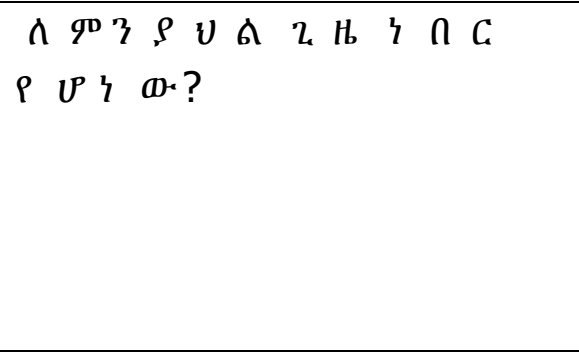 & 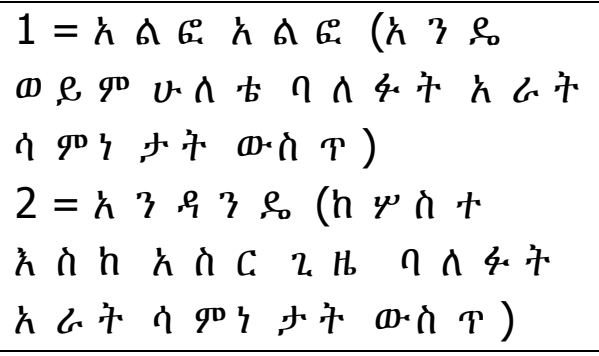 \\
\hline
\end{tabular}




\begin{tabular}{|c|c|c|}
\hline & & 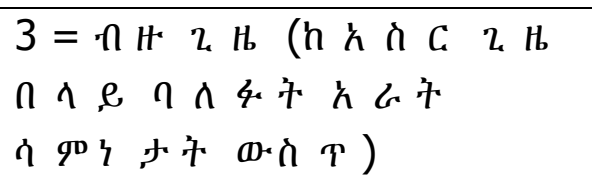 \\
\hline 405 & 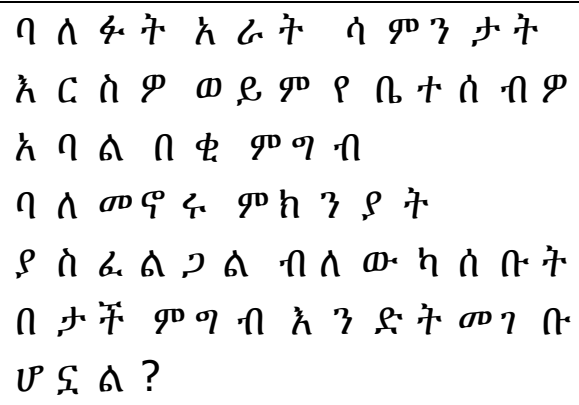 & 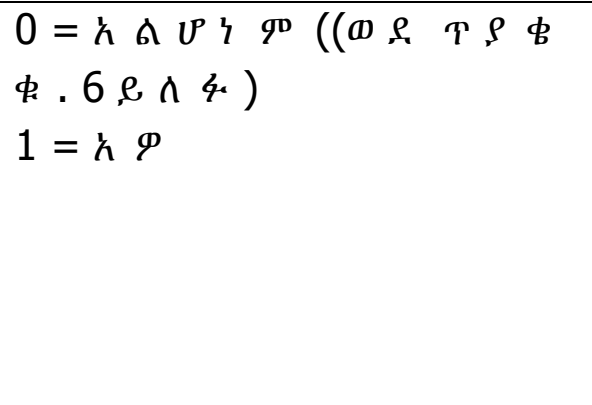 \\
\hline $405 a$ & 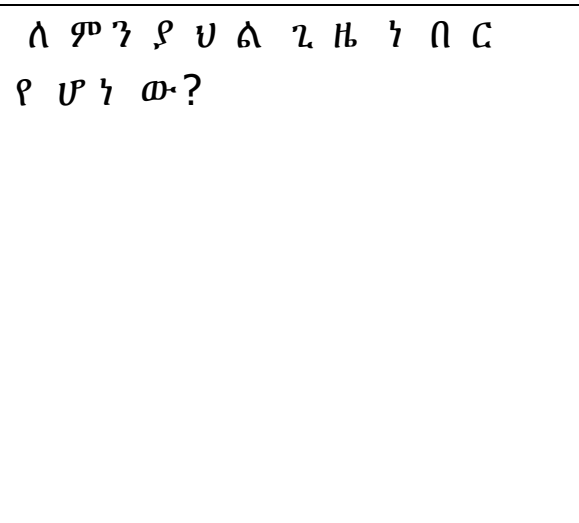 & 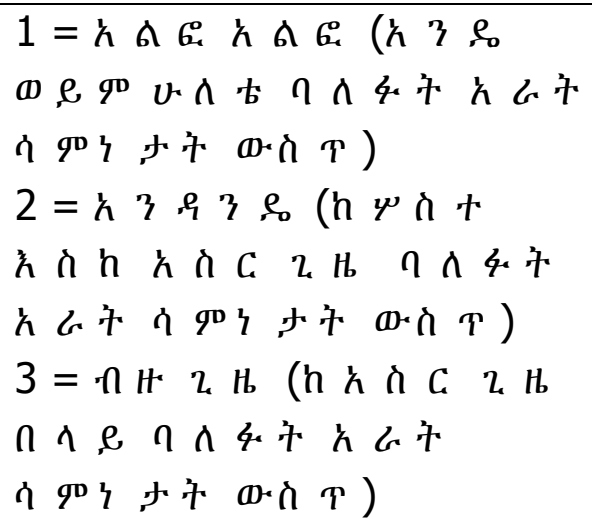 \\
\hline 406 & 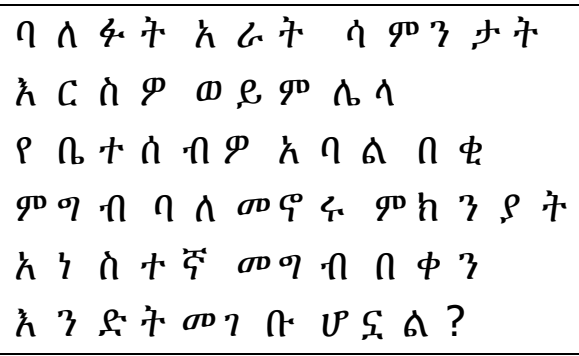 & 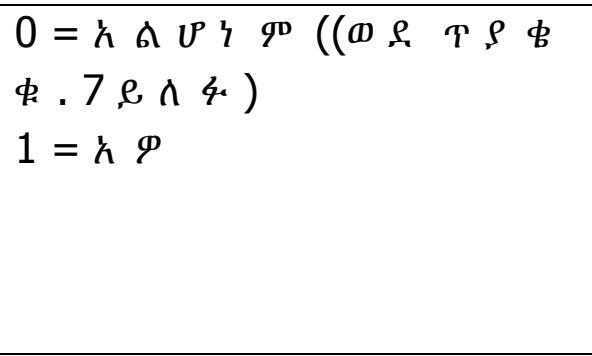 \\
\hline $406 a$ & 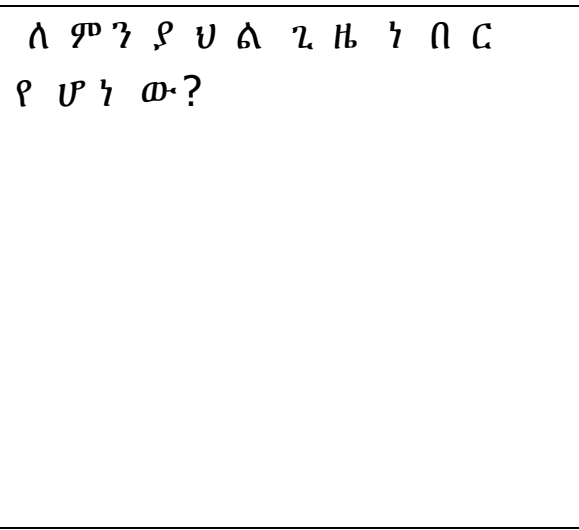 & 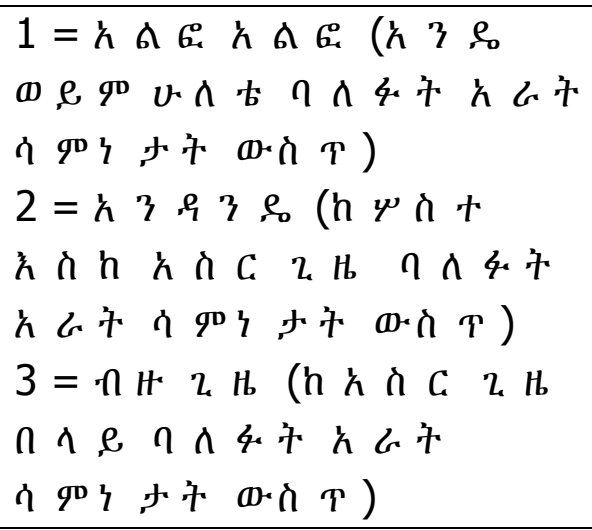 \\
\hline 407 & 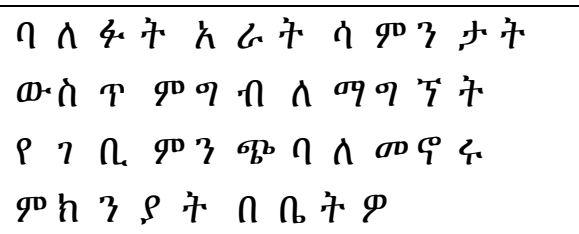 & 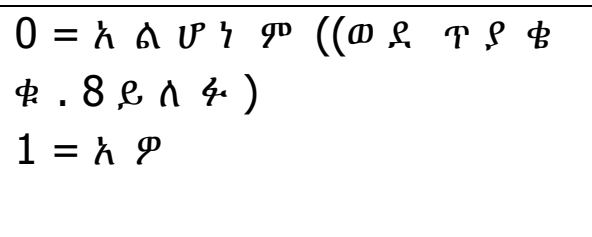 \\
\hline
\end{tabular}




\begin{tabular}{|c|c|c|}
\hline & 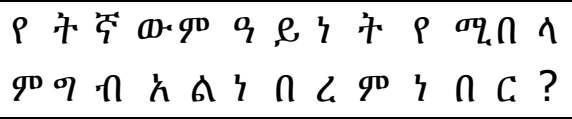 & \\
\hline $407 a$ & 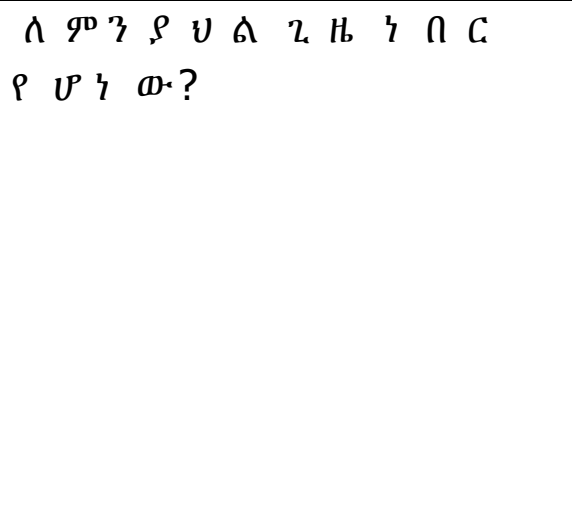 & 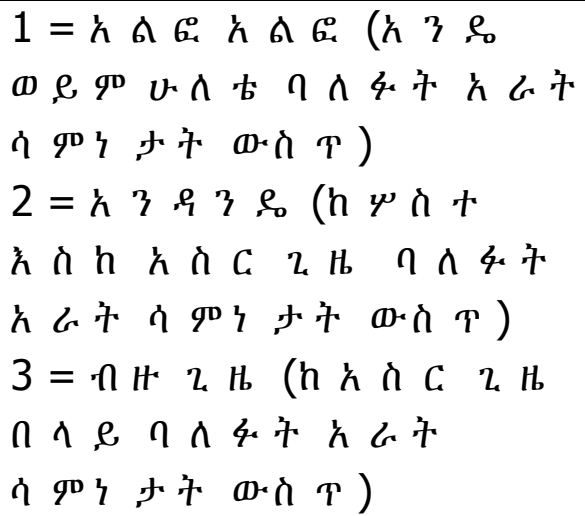 \\
\hline 408 & 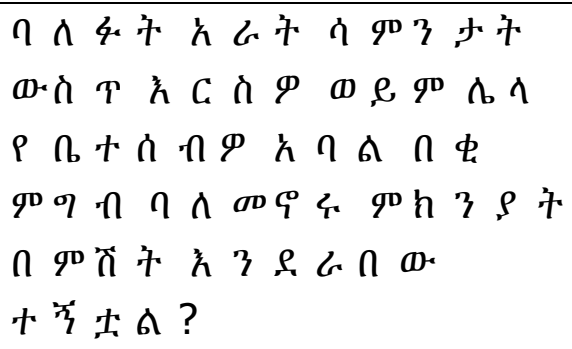 & 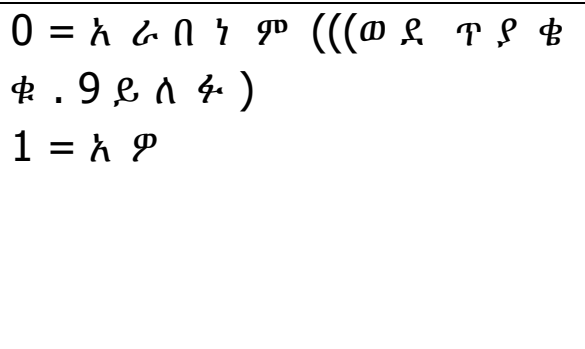 \\
\hline $408 a$ & 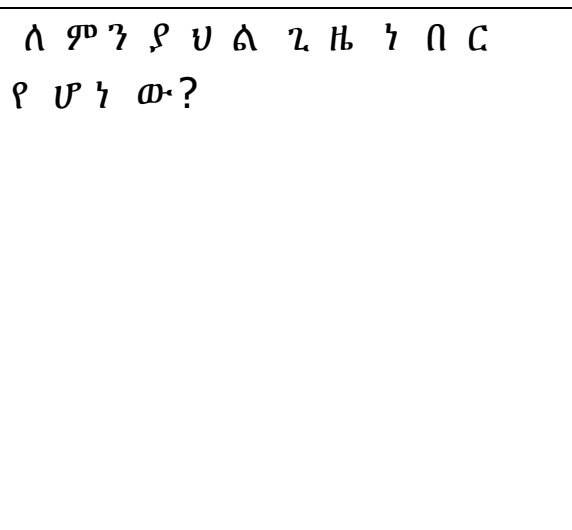 & 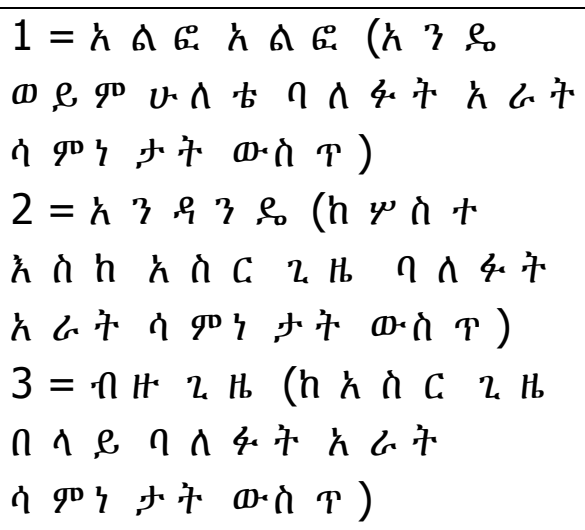 \\
\hline 409 & 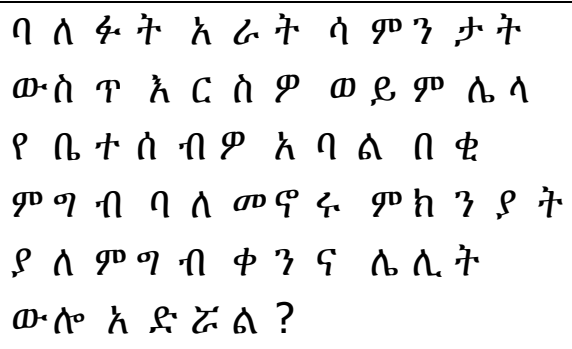 & 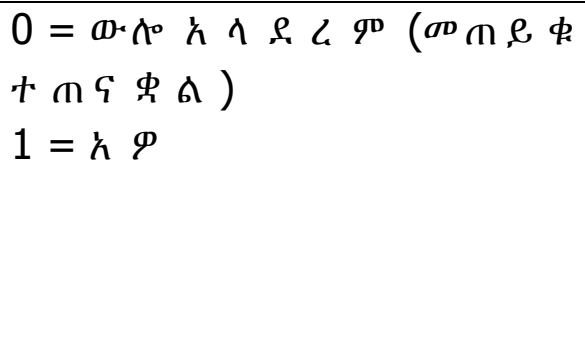 \\
\hline $409 a$ & 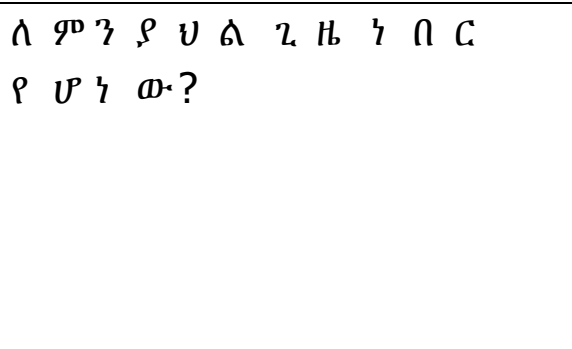 & 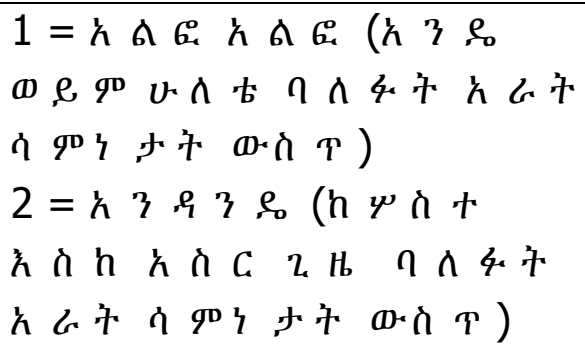 \\
\hline
\end{tabular}




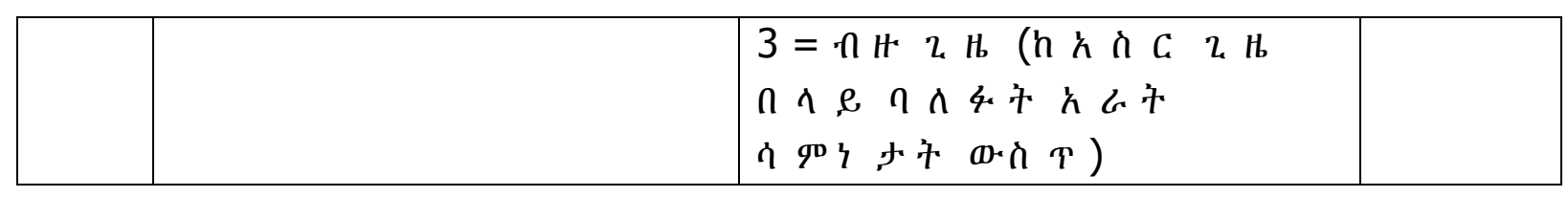

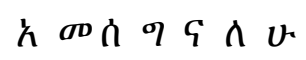

\section{Annex V. HFIAP measurement tool}

The HFIAP indicator categorizes households into four levels of household food insecurity: food secure, and mild, moderately and severely food insecure. Households are categorized as increasingly food insecure as they respond affirmatively to more severe conditions and/or experience those conditions more frequently. Each household category was labeled as: 1 = Food Secure, 2=Mildly Food Insecure, 3=Moderately Food Insecure, 4=Severely Food Insecure. And each category was calculated based on the following assumptions.

- HFIA category $=1$ if $[(\mathrm{Q} 401=0$ or $\mathrm{Q} 401 \mathrm{a}=1)$ and $\mathrm{Q} 402=0$ and $\mathrm{Q} 403=0$ and Q404=0 and Q405=0 and Q406=0 and Q407=0 and Q408=0 and Q409=0]

- HFIA category = 2 if $[(\mathrm{Q} 401 \mathrm{a}=2$ or $\mathrm{Q} 401 \mathrm{a}=3$ or $\mathrm{Q} 402 \mathrm{a}=1$ or $\mathrm{Q} 402 \mathrm{a}=2$ or $\mathrm{Q} 402 \mathrm{a}=3$ or $\mathrm{Q} 403 \mathrm{a}=1$ or $\mathrm{Q} 404 \mathrm{a}=1$ ) and $\mathrm{Q} 405=0$ and $\mathrm{Q} 406=0$ and $\mathrm{Q} 407=0$ and $Q 408=0$ and $Q 409=0$ ] 
- HFIA category $=3$ if $[(\mathrm{Q} 403 \mathrm{a}=2$ or $\mathrm{Q} 403 \mathrm{a}=3$ or $\mathrm{Q} 404 \mathrm{a}=2$ or $\mathrm{Q} 404 \mathrm{a}=3$ or $\mathrm{Q} 405 \mathrm{a}=1$ or $\mathrm{Q} 405 \mathrm{a}=2$ or $\mathrm{Q} 406 \mathrm{a}=1$ or $\mathrm{Q} 406 \mathrm{a}=2$ ) and $\mathrm{Q} 407=0$ and $\mathrm{Q} 408=0$ and Q409=0]

- HFIA category $=4$ if $[\mathrm{Q} 405 \mathrm{a}=3$ or $\mathrm{Q} 406 \mathrm{a}=3$ or $\mathrm{Q} 407 \mathrm{a}=1$ or $\mathrm{Q} 407 \mathrm{a}=2$ or $\mathrm{Q} 407 \mathrm{a}=3$ or $\mathrm{Q} 408 \mathrm{a}=1$ or $\mathrm{Q} 408 \mathrm{a}=2$ or $\mathrm{Q} 408 \mathrm{a}=3$ or $\mathrm{Q} 409 \mathrm{a}=1$ or $\mathrm{Q} 409 \mathrm{a}=2$ or $\mathrm{Q} 409 \mathrm{a}=3]$. To determine the overall prevalence of household food insecurity the four categories were farther categorized into two. These dichotomous outcomes are HFIA category $1=$ food secure category and the rest three combined to give food insecure household category. [47]

Annex VI. Food insecurity status by some socio-economic characteristics in rural communities of Gondar City Administration, 2011. 
Socio-demographic characteristics

\begin{tabular}{|c|c|c|c|}
\hline characteristics & $\begin{array}{l}\text { Food insecure } \\
\text { Frequency (\%) }\end{array}$ & $\begin{array}{c}\text { Food secure } \\
\text { Frequency (\%) }\end{array}$ & $\begin{array}{c}\text { Total } \\
\text { Frequency (\%) }\end{array}$ \\
\hline \multicolumn{4}{|l|}{ Relation of the head with } \\
\hline \multicolumn{4}{|l|}{ members of the $\mathrm{Hh}$} \\
\hline Head & 308() 58.8 & $216(41.2)$ & $524(73.4)$ \\
\hline Spouse & $121(65.8)$ & $63(34.2)$ & $184(25.8)$ \\
\hline Sister/Brother & $4(80)$ & $1(20)$ & $5(0.7)$ \\
\hline Relative & $1(100)$ & 0 & $1(0.1)$ \\
\hline \multicolumn{4}{|l|}{ Ethnicity } \\
\hline Amhara & $433(60.8)$ & 279(39.2) & $712(99.7)$ \\
\hline Oromo & $1(50)$ & $1(50)$ & $2(0.3)$ \\
\hline \multicolumn{4}{|l|}{ Religion } \\
\hline Orthodox & $429(60.7)$ & $278(39.3)$ & $707(99)$ \\
\hline Muslim & $3(60)$ & $2(40)$ & $5(0.7)$ \\
\hline Catholic & $2(100)$ & 0 & $2(0.3)$ \\
\hline \multicolumn{4}{|l|}{ Occupation } \\
\hline Farmer & $358(57.5)$ & $265(42.5)$ & $623(87.3)$ \\
\hline Petty trade & $7(100)$ & 0 & $7(1)$ \\
\hline Civil servant & $3(42.9)$ & $4(51.1)$ & $7(1)$ \\
\hline Daily laborer & $53(91.4)$ & $5(8.6)$ & $58(8.1)$ \\
\hline Student & $3(42.9)$ & $4(57.1)$ & $7(1)$ \\
\hline Unemployed & $3(75)$ & $1(25)$ & $4(0.6)$ \\
\hline \multicolumn{4}{|l|}{ Fruits \&vegetables } \\
\hline Yes & $90(39.3)$ & $139(60.7)$ & $229(32$. \\
\hline No & $344(70.9)$ & $141(29.1)$ & $485(67.9)$ \\
\hline \multicolumn{4}{|l|}{ Uses of fruits \& vegetables } \\
\hline Only for sell & $3(30)$ & $7(70)$ & $10(1.4)$ \\
\hline Partially for sell & $69(47.6)$ & $76(52.4)$ & $145(20.3)$ \\
\hline Only for consumption & $52(41.6)$ & $73(58.4)$ & $125(17.5$ \\
\hline
\end{tabular}


Household assets

\begin{tabular}{|c|c|c|c|c|}
\hline & & $\begin{array}{c}\text { Food insecure } \\
\text { Frequency }(\%)\end{array}$ & $\begin{array}{c}\text { Food secure } \\
\text { Frequency }(\%)\end{array}$ & $\begin{array}{c}\text { Total } \\
\text { Frequency }(\%)\end{array}$ \\
\hline \multicolumn{5}{|l|}{ Bicycle } \\
\hline & Yes & $3(60)$ & $2(40)$ & $5(0.7)$ \\
\hline & No & $431(60.8)$ & $278(39.2)$ & $709(99.3)$ \\
\hline \multicolumn{5}{|l|}{ Bajaj } \\
\hline & Yes & $3(100)$ & 0 & $3(0.4)$ \\
\hline & No & $431(60.6)$ & $280(39.4)$ & $711(99.6)$ \\
\hline \multicolumn{5}{|l|}{ Radio } \\
\hline & Yes & $110(50.9)$ & $106(49.1)$ & $216(30.3)$ \\
\hline & No & $324(65.1)$ & $174(34.9)$ & $498(69.7)$ \\
\hline \multicolumn{5}{|c|}{ Television } \\
\hline & Yes & $8(80)$ & $2(20)$ & $10(1.4)$ \\
\hline & No & $426(60.5)$ & $278(39.5)$ & $704(98.6)$ \\
\hline \multicolumn{5}{|l|}{ Car } \\
\hline & Yes & 0 & $1(100)$ & $1(0.1)$ \\
\hline & No & $434(60.9)$ & $279(39.1)$ & $713(99.9)$ \\
\hline
\end{tabular}


Presence of vectors in the household

\begin{tabular}{|c|c|c|c|c|}
\hline \multirow{2}{*}{\multicolumn{2}{|c|}{ Vector }} & Food insecure & Food secure & Total \\
\hline & & Frequency (\%) & Frequency (\%) & Frequency (\%) \\
\hline \multicolumn{5}{|c|}{ Bedbug } \\
\hline & Yes & $166(57.2)$ & $124(42.8)$ & $290(40.6)$ \\
\hline & No & $268(63.2)$ & $156(36.8)$ & $424(59.4)$ \\
\hline \multicolumn{5}{|l|}{ Fleas } \\
\hline & Yes & $254(64)$ & $143(36)$ & $397(55.6)$ \\
\hline & No & $180(56.8)$ & $137(43.2)$ & $317(44.4)$ \\
\hline \multicolumn{5}{|c|}{ Ginger fleas } \\
\hline & Yes & $9(75)$ & $3(25)$ & $12(1.7)$ \\
\hline & No & $425(60.5)$ & $277(39.5)$ & $702(98.3)$ \\
\hline \multicolumn{5}{|l|}{ Lice } \\
\hline & Yes & $15(57.7)$ & $11(42.3)$ & $26(3.6)$ \\
\hline & No & $419(60.9)$ & $269(39.1)$ & $688(96.4)$ \\
\hline \multicolumn{5}{|c|}{ Mosquitoes } \\
\hline & Yes & $202(73.7)$ & $72(26.3)$ & $274(38.4)$ \\
\hline & No & $232(52.7)$ & $208(47.3)$ & $440(61.6)$ \\
\hline \multicolumn{5}{|c|}{ Cockroach } \\
\hline & Yes & $9(52.9)$ & $8(47.1)$ & $17(2.4)$ \\
\hline & No & $425(61)$ & 272(39) & 697(97.6) \\
\hline
\end{tabular}




\title{
Annex VII. Operational Manual for Data Collectors(English)
}

\author{
UNIVERSITY OF GONDAR \\ COLLEGE OF MEDICINE AND HEALTH SCIENCES \\ SCHOOL OF PUBLIC HEATLTH
}

Operational Manual for Data Collection on Prevalence of Food Insecurity and Associated Factors

April 11, 2011

Gondar 


\section{INFORMANT INTERVIEW GUIDE}

The Key Informant Interview Guide describes the type of discussion that is required in order to develop words/phrases, examples, and definitions that are adapted to the local context so that questions are understandable to survey respondents. The instruction following each question and set of probes below specifies whether the modification should be done as a phrase, definition, or example.

For each household respondent always begin by introducing yourself as stated in the consent form.

Q1: Did you worry that your household would not have enough food?

- By "household" we mean those of you that sleep under the same roof and take meals together at least four days a week.

Q2: Were you or any household member not able to eat the kinds of foods you preferred because of a lack of resources?

- By "kinds of foods you preferred" we mean foods that food secure people eat that food insecure people cannot afford to eat. E.g. Teff Enjera, meat, egg, milk, yoghurt, etc

- Whenever we say "lack of resources", we mean not having the means to get food, either through growing it, purchasing it, or trading for it.

Q3: Did you or any household member have to eat a limited variety of foods due to a lack of resources?

- When we say "a limited variety of foods", we want to mean an undesired monotonous diet for an extended period of days. E.g. Enjera and shiro only.

Q4: Did you or any household member have to eat some foods that you really did not want to eat because of a lack of resources to obtain other types of food?

- "A food you really did not want to eat" might include Sorghum's Enjera, boiled grains ( Nifro), roasted grains ( kollo), etc. 
Q5: Did you or any other household member have to eat a smaller meal than you felt you needed because there was not enough food?

- By "meal" we mean the major eating occasions (not including snacks). Or can be asked as:-

- Did you or any household member eat less in either the morning or evening meal than you felt you needed because there was not enough food?

Q6: Did you or any household member have to eat fewer meals in a day because there was not enough food?

- This question asks about eating "fewer meals in a day" than the social norm. can be asked as:

- Did you or any household member have to eat fewer than two/three meals in a day because there was not enough food?

Q7: Was there ever no food to eat of any kind in your household because of lack of resources to get food?

- By "no food to eat" we mean that the food was not available in the household and could not be accessed by the household's usual means (e.g. through purchase, from the garden or field, from storage, etc.).

Q8: Did you or any household member go to sleep at night hungry because there was not enough food?

- This question may not require any adaptation.

Q9: Did you or any household member go a whole day and night without eating anything because there was not enough food?

- $f$ This question may not require any adaptation. 


\title{
Annex VIII. Operational Manual (Amharic)
}

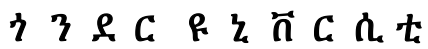 \\ v

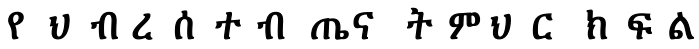

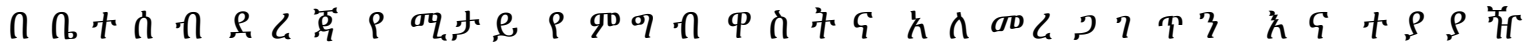

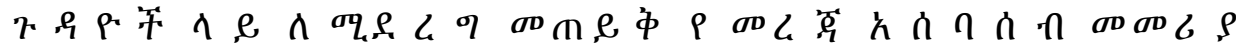

$\sigma q, \rho$ H. $\rho 2003$ q .9d

i $P$ C C 


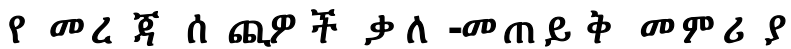

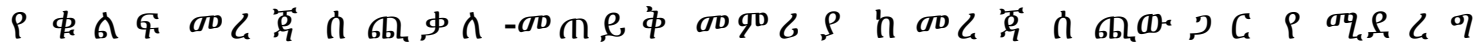

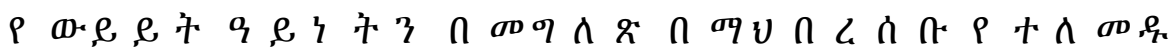

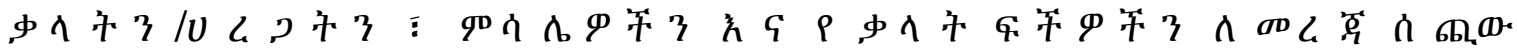
ๆ

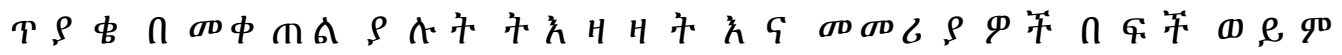

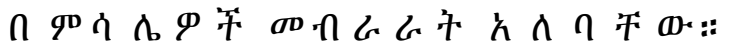

入

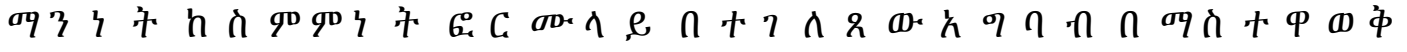

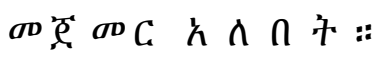

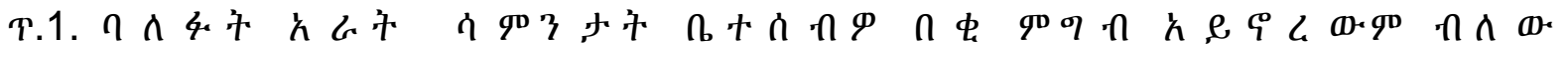

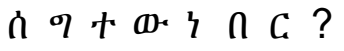

$>$ "

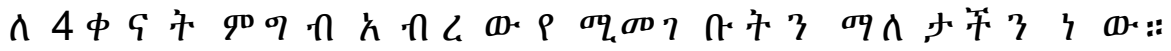

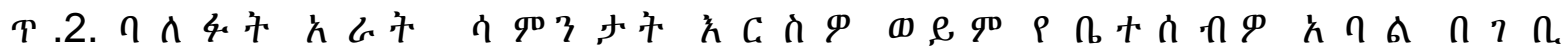
q03 б力

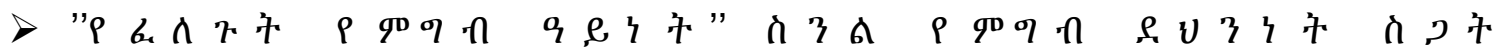

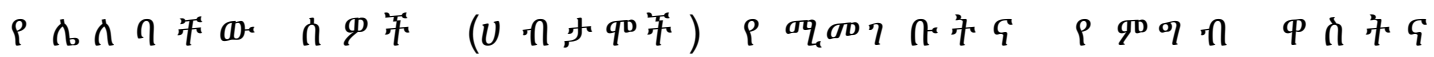
么八

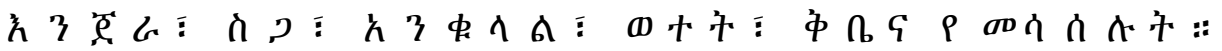

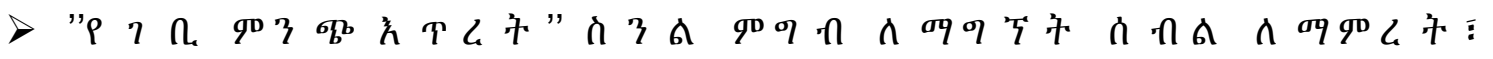

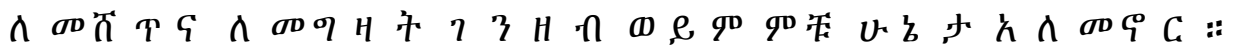

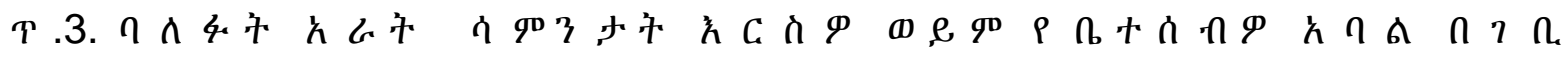
q03 б 太 3 只市

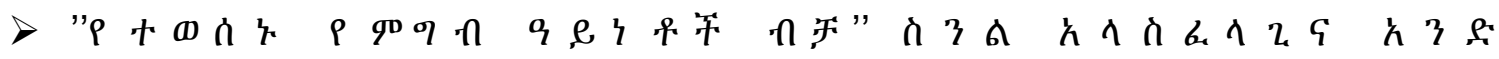

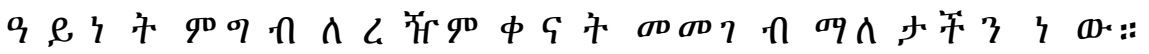




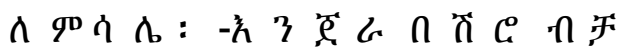

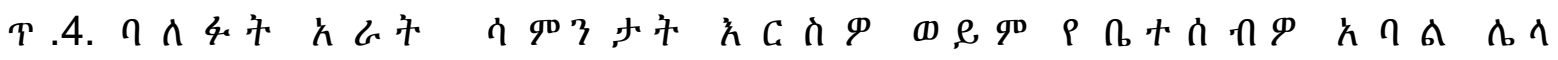

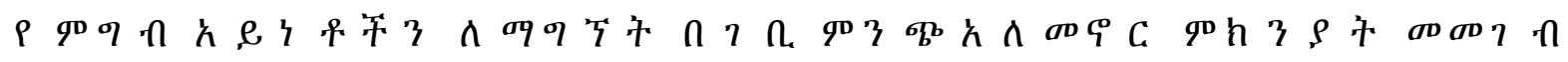

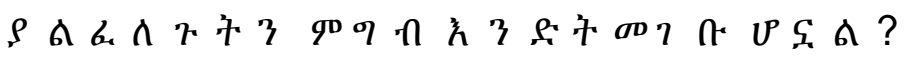

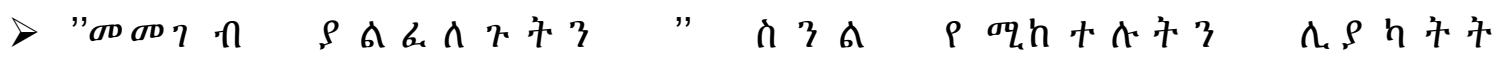
连入 P odd d 内市：

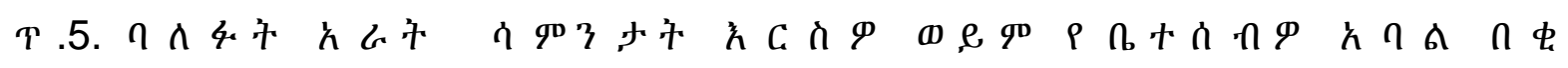

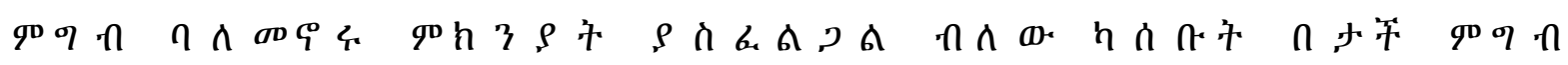
去 3 穴

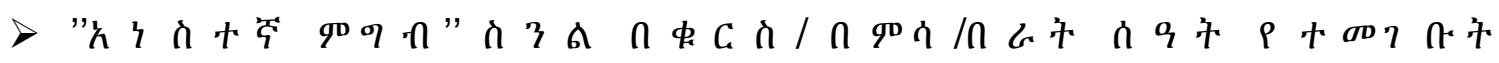

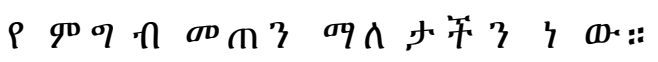

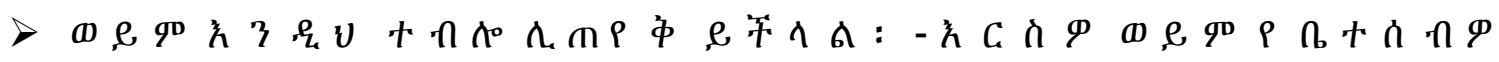

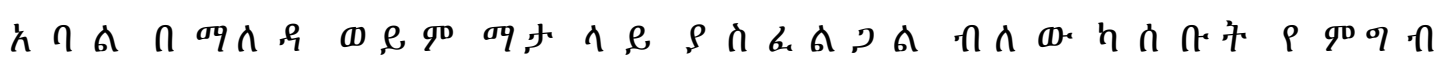

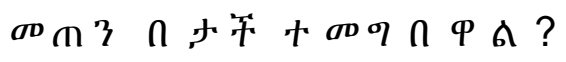

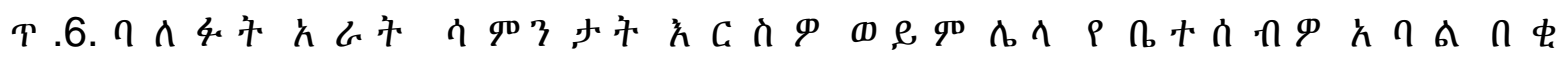

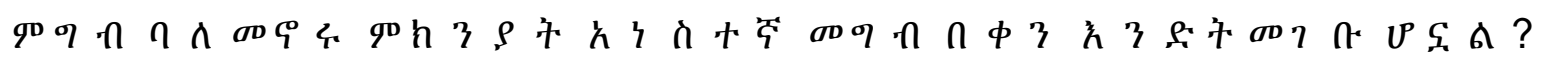

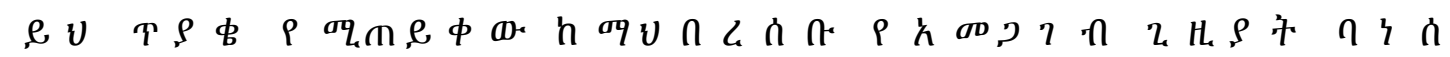

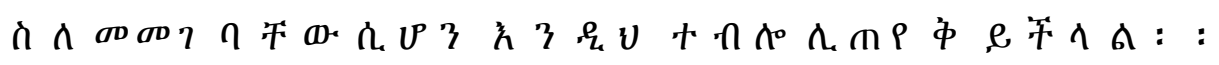

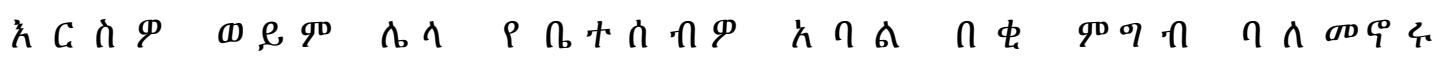

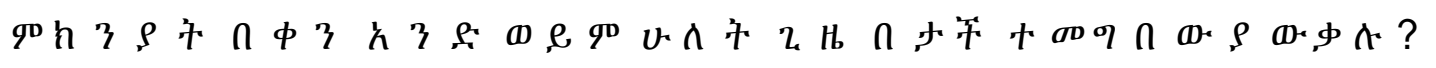

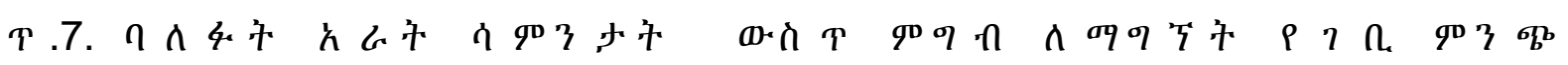

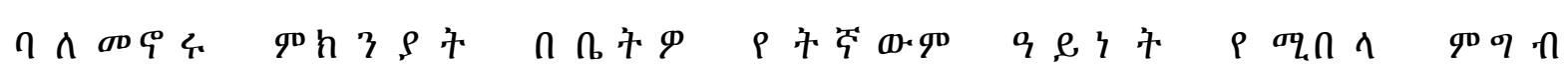
h 


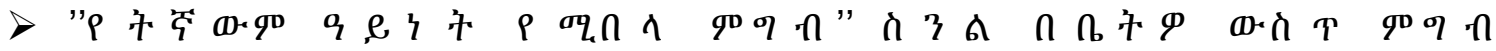

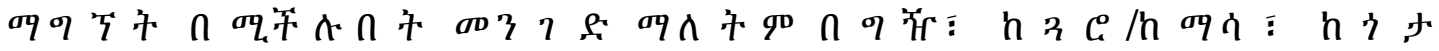

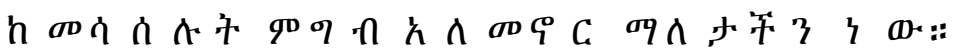

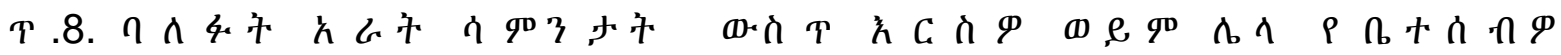

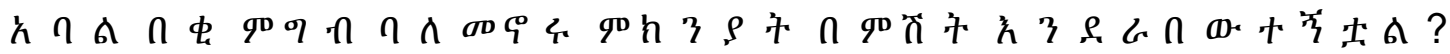

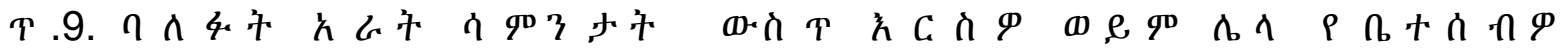
么クム

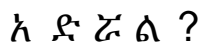

\section{Annex IX. Assurance of Investigator}

The undersigned agrees to accept responsibility for the scientific, ethical and technical conduct of the research project and for provision of required progress reports as pre terms and conditions of the research and publications office of the University of Gondar.

Name of the student:

Date: Signature:

Approval of the advisor (s)

Advisors

Name

Signature

Date

1.

2. 


\section{Annex X. Declaration}

I, the undersigned, senior MPH student declare that this thesis is my original work in partial fulfillment of the requirement for the degree of Master of Public Health.

Name: Yirdaw Melese

\section{Signature:}

Place of submission: School of Public Health, College of medicine and Health Sciences, University of Gondar.

Date of Submission:

This thesis work has been submitted for examination with my/our approval as university advisor(s).

\section{Advisors}

Name

1.

2.
Signature

ABC Research Alert, Vol 2, No 2 (2014) 